\title{
Arquitetura residencial verticalizada em São Paulo nas décadas de 1930 e 1940'
}

\begin{abstract}
Maria Lúcia Bressan Pinheiro
RESUMO: O presente trabalho aborda o tema, ainda pouco estudado, da arquitetura residencial verticalizada em São Paulo, nas décadas de 1930 e 1940. A partir de alguns estudos de caso representativos, são apresentadas observações relativas a aspectos como: as estratégias de disseminação da nova forma de morar; as opções estéticas disponíveis; a definição dos programas das unidades e as soluções de planta desenvolvidas. Espera-se evidenciar a riqueza e complexidade do assunto, que se configura não apenas como importante tema da história da arquitetura paulistana, mas, principalmente, como significativo patrimônio cultural da cidade, a ser conhecido e protegido.

PALAVRAS-CHAVE: Apartamentos. Edifícios residenciais. Art Déco. Aluguel. São Paulo. Verticalização.
\end{abstract}

ABSTRACT: The present work addresses the topic, as yet scarcely studied, of high-rise residential architecture in Sao Paulo during the 1940s and 50s. Supported by some representative case studies, observations were drawn on the following aspects: the strategies used to propagate this new dwelling form, the available aesthetical options for these buildings, the definition of these units' purposes and uses and the development of ground plan architectural solutions. This article aims to render evident the great value and complexity of its subject matter, which is not only extremely important as a theme of Sao Paulo's architectural history, but also, and foremostly, as a significant cultural heritage of this city, which should be acknowledged and safeguarded.

KEYWORDS: Apartments. Residential buildings. Art Deco. Renting. Sao Paulo. High-rise Development.

"Quem viu uma casa brasileira, viu quase todas" - estas palavras do engenheiro francês Louis Lèger Vauthier ${ }^{3}$, arguto observador dos usos e costumes residenciais recifenses, foram muitas vezes retomadas em estudos relativos à
1. O presente artigo originase de minha tese de doutoramento Modernizada ou Moderna? A arquitetura em São Paulo, 1938-45, na qual foram analisados todos os projetos publicados na Acrópole, revista paulista de arquitetura, referentes ao período em epígrafe. No que diz respeito ao tema, neste intervalo de tempo a revista publicou 35 prédios de apartamentos residenciais localizados nas cidades de São Paulo e Santos, nos quais baseamos nossas observações - além de 15 edifícios residenciais cariocas.

2. Docente da Faculdade de Arquitetura Urbanismo da Universidade de São Paulo. E-mail:<mlbp@usp.br>.

3. Cf. Louis Léger Vauthier (1975, p. 37). 
4. Embora a construção de edifícios com mais de 4 andares na área central da cidade de São Paulo remonte à década de 1910, tal processo circunscreveu-se, então, a iniciativas pontuais e a edifícios de escritórios, mantendo-se praticamente restrito ao chamado Triângulo. É o caso do Edifício Guinle (1912), com 8 andares, projetado pelo engenheiro-arquiteto Hipólito $\mathrm{Pu}$ jol Jr., o primeiro edifício em altura da cidade, com estrutura de concreto armado calculada matematicamente. Na década de 1920, destaca-se o Edifício Sampaio Moreira (1924), projeto de Cristiano Stockler das Neves que, com seus 13 andares mais porão e ático,é considerado nosso primeiro arranha-céu; mas é certo que, por muito tempo, reinou soberano, com seus 26 andares, o Edifício Martinelli, inaugurado em 1929. Entretanto, é só a partir da década de 1930 que o processo se tornou irreversível, extrapolando os limites do centro antigo da cidade e englobando a função residencial.Aliás, as vias alargadas que compunham o chamado "Anel de Irradiação" - a rótula projetada por Prestes Maia em seu Plano de Avenidas - constituíram um dos vetores prediletos da verticalização residencial.

5.A bibliografia a respeito do tema é bastante escassa. Os estudos acerca da verticalização paulistana têm privilegiado sua vertente modernista, caracterizada pela presença dos "cinco pontos" preconizados por Le Corbusier, a saber:planta livre, fachada livre, janelas contínuas, telhado-jardim e uso de pilotis. Em São Paulo, nas décadas de 1930 e 1940, são raríssimos os edifícios residenciais que apresentam tais características entre eles, por exemplo,o Edifício Esther (1936), dos arquitetos cariocas Ademar Marinho e Álvaro Vital Brasil.

6. Em nossa pesquisa na revista Acrópole, todos os edifícios residenciais publicados até 1942 pertenciam a arquitetura residencial brasileira dos primeiros séculos, demonstrando sua pertinência genérica a esse respeito. Entretanto, é impossível empregar palavras análogas diante das múltiplas configurações que, quase um século mais tarde, a arquitetura residencial assumiria em São Paulo, no início de sua fase verticalizada ${ }^{4}$. É realmente fascinante o tema da habitação vertical em São Paulo nas décadas de 1930 e 1940: as estratégias para sua disseminação, derrubando arraigados preconceitos; a definição dos programas das unidades; as soluções de planta desenvolvidas; a incorporação ou não das dependências destinadas às empregadas no apartamento-tipo; a relação entre a área social e a área íntima de cada unidade - tudo isto está a merecer estudos aprofundados a partir de amostragens quantitativamente expressivas ${ }^{5}$. Entretanto, pode-se desde já arriscar algumas observações, capazes de evidenciar a riqueza e complexidade do assunto.

Desde logo cabe destacar que as características projetuais dos primeiros edifícios residenciais paulistanos atendem, antes de mais nada, à lógica subjacente à própria verticalização da cidade - isto é, a de auferir lucros mediante a multiplicação do solo urbano. Como peculiaridade, constata-se que, a despeito da vigência do Decreto 5.491, de 25/06/1928, que instituía a figura jurídica do condomínio, estes prédios eram construídos "para renda" por um único investidor, proprietário, portanto, de todos os apartamentos - geralmente destinados a serem alugados. Tal situação só vai se alterar a partir de 1942, com a promulgação da Lei do Inquilinato, que, ao congelar os valores dos aluguéis, inviabilizou a continuidade deste tipo de investimento imobiliário, que passou a ser substituído pelo sistema de condomínió. A esse respeito, é significativa a notícia - publicada na revista de arquitetura Acrópole - de que o primeiro condomínio de apartamentos de São Paulo "está sendo erigido [...] na Rua Paraíso, esquina da Rua Abílio Soares" (Figuras 1 e 2) 7.

Assim, guiados pela lógica do mercado imobiliário e pelo imperativo do barateamento da construção, os projetos de tais edifícios estão distantes de quaisquer inovações e ousadias técnicas, que não aquelas estritamente necessárias para sua concretização. A ocupação dos terrenos é a máxima possível, independentemente de fatores como orientação e insolação; a primazia da fachada principal é nítida; os pavimentos-tipo apresentam unidades heterogêneas, com soluções de planta alheias às necessidades funcionais e da comodidade; tudo isso agravado pela irregularidade dos lotes de origem colonial.

Evidentemente, a possibilidade de realização de edifícios em altura depende do domínio de uma tecnologia apropriada que, em São Paulo, foi o concreto armado ${ }^{8}$. Entretanto, nos edifícios em estudo, sua utilização mantevese absolutamente rotineira, distante de qualquer tentativa de exploração das possibilidades plásticas do material. Trata-se quase invariavelmente de estruturas em pilar e viga, calculadas sem grandes ousadias, vedadas em tijolos e associadas a lajes planas - que constituem os pisos dos edifícios -, sem qualquer preocupação de configurar plantas-livres ${ }^{9}$. Deve-se lembrar que, no período em 

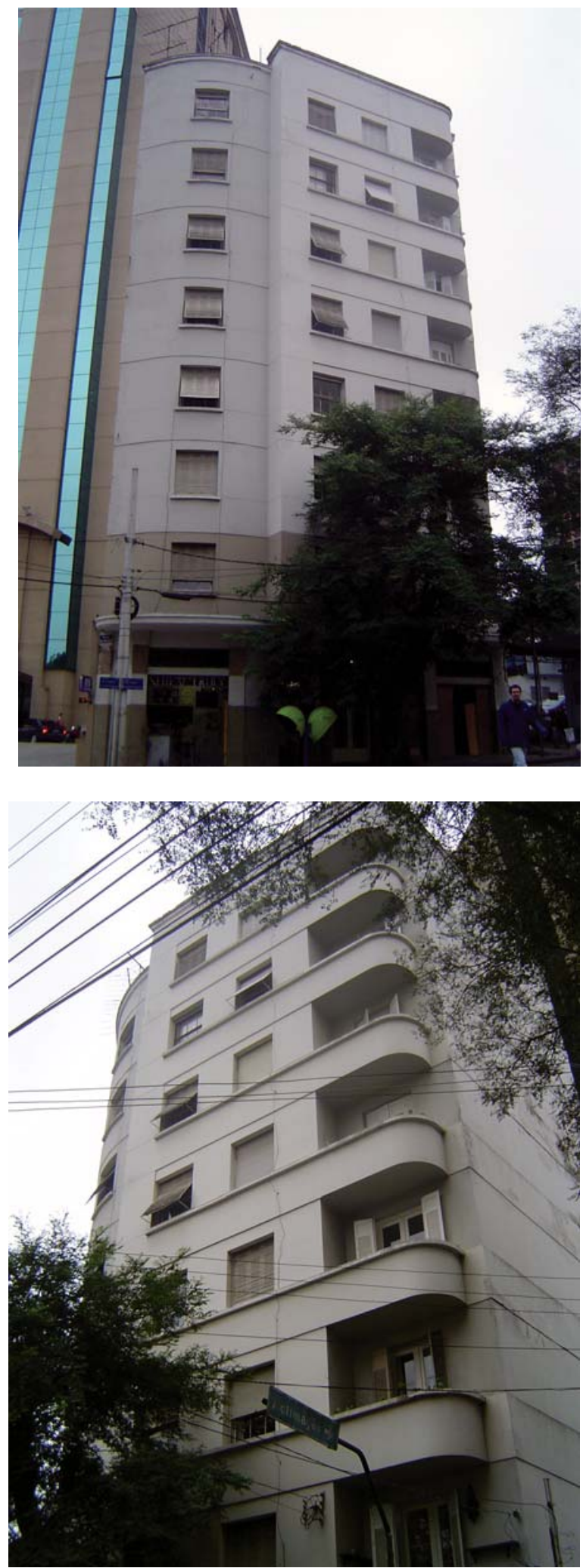

Figura 1 - Primeiro condomínio de apartamentos de São Paulo, de acordo com a revista Acrópole. Fachada para a Rua Abílio Soares e esquina da Rua do Paraíso. Fotografia de Paulo César Garcez Marins, 2008.
Figura 2 - Fachada para a Rua Abílio Soares do primeiro condomínio de apartamentos de São Paulo, conforme a revista Acrópole. Fachada. Fotografia de Paulo César Garcez Marins, 2008. 
um único proprietário. É só neste ano que aparece o primeiro projeto de edifício de apartamentos em sistema de condomínio - o Edifício Biarritz, localizado em Santos -, acompanhado da notícia mencionada (Acrópole, $\mathrm{n}$. 52, ago. 1942, p. 157). Não obstante, prédios de apartamentos de um único proprietário parecem ter continuado a superar o número de condomínios, a julgar pela amostragem publicada em Acrópole.

7. Acrópole (ago. 1942, p. 157).Trata-se de uma situação substancialmente diversa daquela do Rio de Janeiro, onde os condomínios parecem ter predominado já ao longo da década de 1930.A respeito, ver José Eduardo de Assis Lefèvre (1999, p. 248-249); e também Lílian Fessler Vaz (1994). Cabe ressaltar que, dos 15 edifícios residenciais cariocas publicados em Acrópole, identificados em nossa pesquisa, a maioria quase absoluta foi construída em sistema de condomínio.

8. Entretanto, o emprego de estruturas metálicas pode ter sido mais frequente do que se costuma pensar, a julgar por exemplos como o do edifício do London \& River Plate Bank Limited, ruas Boa Vista, 185 e XV de Novembro, 324-336, pelo escritório Lindenberg,Alves e Assumpção. Conforme fotografias de sua construção, publicadas no álbum de projetos do escritório, a estrutura do edifício - ali identificado como Banco Comercial do Estado de São Paulo - é em vigas metálicas "Wirendel" [sic]. O mesmo sistema foi empregado pelo escritório na Casa Sloper, rua Direita, 226. Não temos informações sobre a data de construção de tais edifícios.

9. A esse respeito, configuram-se como exceções o já mencionado Edifício Esther, construído entre 1936-1938, e o novo edifício da Secretaria da Fazenda, de Ferruccio questão, a produção brasileira de cimento era insuficiente para atender à demanda do setor de construção civil, o que encarecia bastante o seu custo.

Por outro lado, em nosso clima tropical, a utilização de lajes planas na cobertura de edifícios teve forçosamente de esperar o aperfeiçoamento dos processos para sua impermeabilização ${ }^{10}$. Assim, todos os prédios construídos em São Paulo entre 1930 e o final da década de 1940 têm suas lajes de cobertura protegidas com telhados tradicionais, de estrutura de madeira e telhas francesas ou - mais raramente - telhas onduladas Eternit. Alguns deles, entretanto, chegaram a incorporar os telhados-jardim preconizados por Le Corbusier em parte de suas coberturas; além do próprio Edifício Esther, legítimo representante da arquitetura moderna carioca construído em São Paulo, a solução está presente em edifícios como o Gonçalves Biar "1 , av. São João, 1430, projetado por Taddeu Giuzio (Figuras 3 e 4); e no Edifício Regência, que comentaremos em maior detalhe a seguir (Figura 20) ${ }^{12}$. Mais freqüente era a presença de terraços descobertos ocupando parte do último piso do edifício, porém sem qualquer tipo de ajardinamento, como ocorre no Prédio Zena ${ }^{13}$, rua Frederico Abranches (Figuras 5 e 6), e em vários outros edifícios, como o Santa Amália, comentado mais adiante; a solução é encontrada até mesmo em edifícios de escritórios, como é o caso do Sampaio Moreira, de Cristiano Stockler das Neves, projetado em 1924

Porém, outros aspectos advogados por Le Corbusier - como pilotis, plantas e fachadas livres - encontram-se ausentes destes edifícios. A grande maioria deles constitui, aliás, exemplos daquela arquitetura - tão característica do centro de São Paulo - que, na falta de uma bibliografia consolidada a respeito, optamos por chamar de Art déco. Trata-se, na verdade, de versões mais ou menos simplificadas desse estilo, como discutiremos mais adiante.

O estilo Art déco constitui, precisamente, uma de nossas manifestações arquitetônicas mais facilmente reconhecíveis - e menos estudadas. Embora não seja nossa intenção discorrer aqui sobre o tema, de forma ampla, cabe explicitar nosso entendimento a respeito. Trata-se de uma arquitetura descompromissada quanto a princípios teóricos gerais - especialmente a relação forma-função, tão cara à arquitetura moderna - e caracterizada pelo despojamento na ornamentação, que, entretanto, continua presente, buscando remeter-nos aos signos dos "tempos modernos": a máquina e suas formas geometrizadas, a velocidade, a eletricidade etc. A esse respeito, cabe destacar que o Art déco sempre foi suscetível a influências dos acontecimentos do momento, rapidamente veiculados pelos meios de comunicação de massa disseminados no período: o cinema, as revistas ilustradas, o rádio, a propaganda, etc. ${ }^{14}$. Tais fontes de inspiração - bastante diversificadas, como se vê - coexistem com fortes vínculos com a tradição: além da ênfase decorativa, já destacada, deve-se mencionar a manutenção, em muitos casos, do método Beaux-Arts de composição ${ }^{15}$, manifesto numa busca de simetria e axialidade na distribuição da planta. Aliás, possivelmente foi esta solução de compromisso o que the garantiu tão grande e rápida - aceitação no mundo inteiro, assim como ocorreu entre nós. 


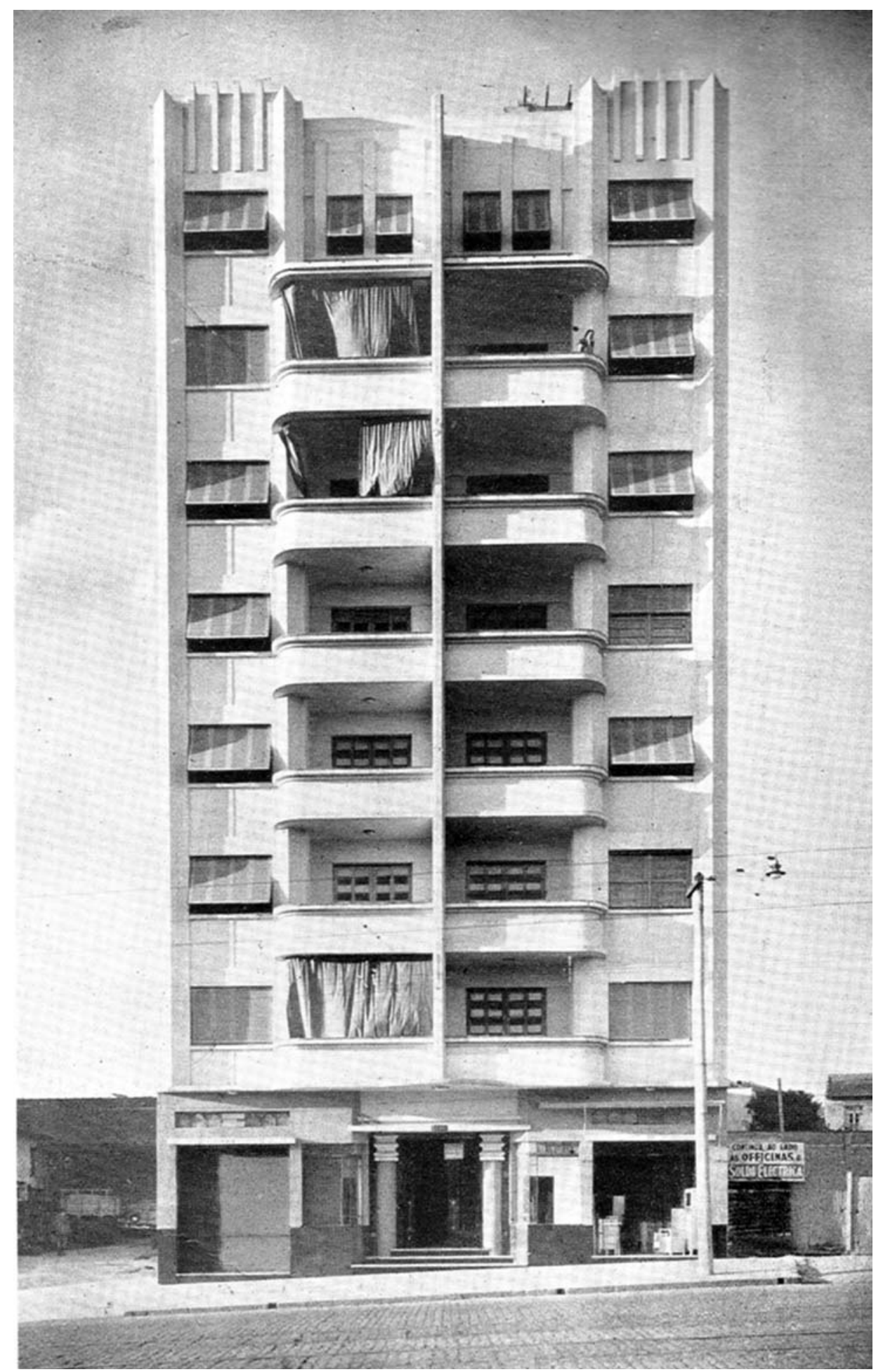

Figura 3 - Fachada do Edifício Gonçalves Biar, Av. São João, projetado por Tadeu Giuzio (ACRÓPOLE, abr. 1939, p. 51 ). 


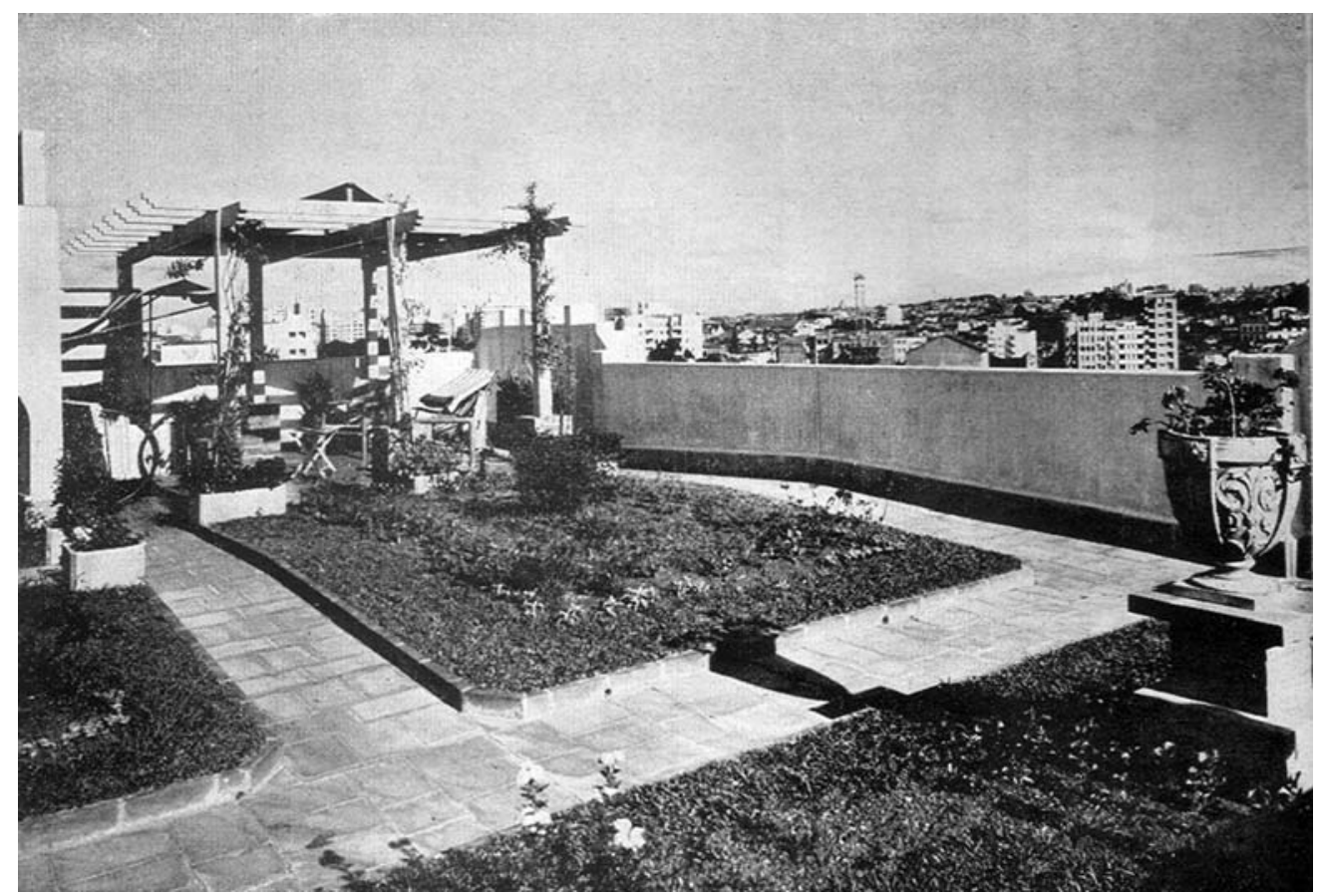

Figura 4 - Vista do terraço-jardim do Edifício Gonçalves Biar (ACRÓPOLE, abr. 1939, p. 53).

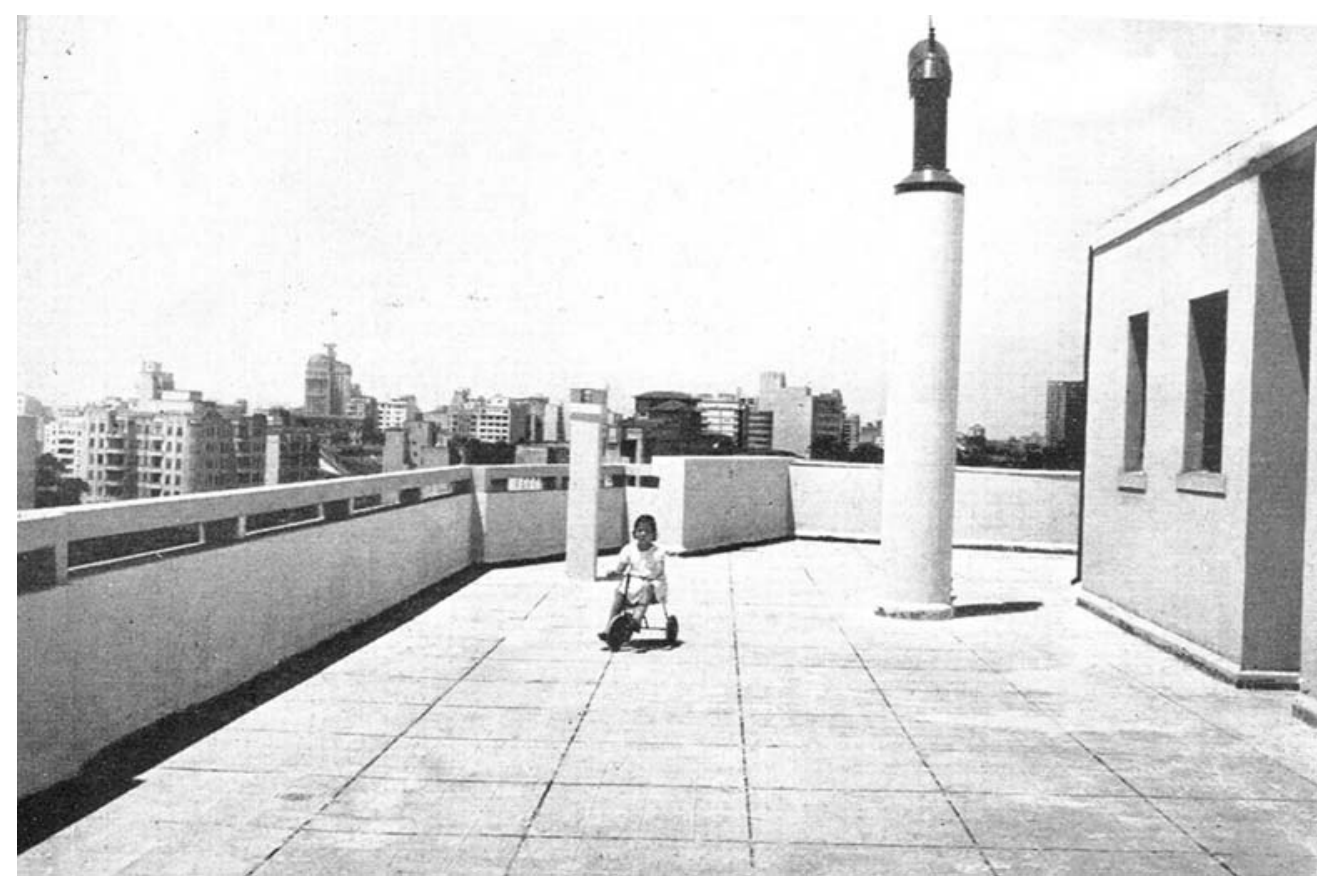

Figura 5 - Terraço na cobertura do Prédio Zena (ACRÓPOLE, mar. 1940, p. 36). 


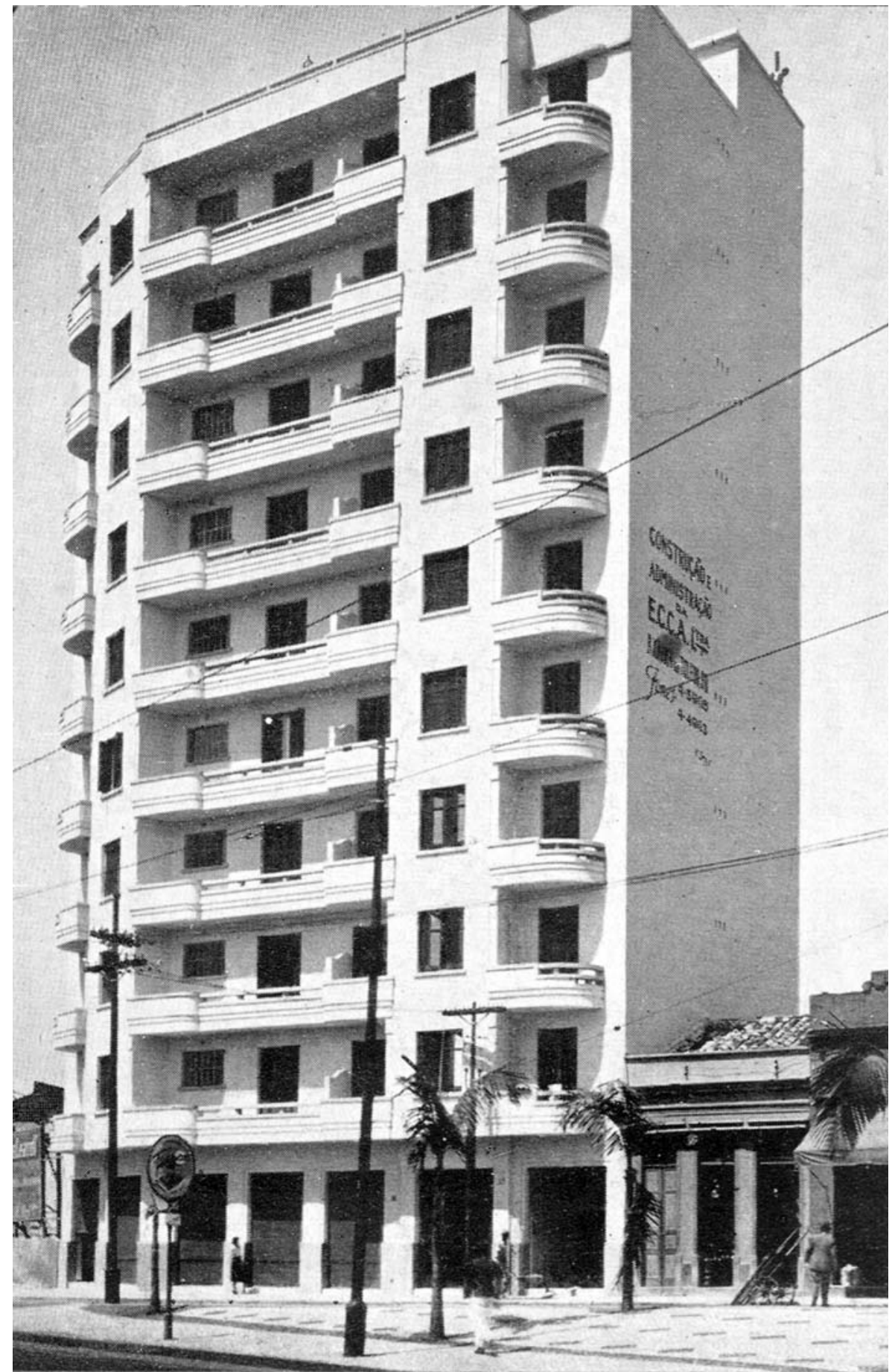

Figura 6 - Fachada principal do Prédio Zena, rua Frederico Abranches com rua Sebastião Pereira, projetado pela Empresa Construtora Concreto Armado Ltda. (ACRÓPOLE, mar. 1940, p. 34). 
em que acervos de escritórios de arquitetura encontram-se disponíveis em bibliotecas públicas, a única forma de datar com precisão um projeto de arquitetura, ou a data de construção de um edifício, é através da consulta direta aos arquivos da Prefeitura Municipal de São Paulo, onde se localiza o respectivo processo de aprovação. Para tanto, existe um procedimento burocrático a ser seguido e certos dados devem ser fornecidos a prio$r i$, tais como: data de construção; endereço original; dados cadastrais do imóvel; eventualmente, autorização
Em São Paulo, um exemplo emblemático do Art déco é o edifício do Instituło Biológico, projetado em 1928 por Mário Whately, em estrita observância do método Beaux-Arts de composição, claramente perceptível em sua volumetria (Figura 7$)^{16}$. É digna de nota a semelhança entre este edifício e o projeto do aluno Antônio Severo, da Escola Nacional de Belas Artes do Rio de Janeiro, para um "Palácio para Convenções Rotarianas" publicado em 30.5.1930 em O Jornal, como ilustração de uma entrevista com o arquiteto Archimedes Memória, professor de projeto daquela instituição e seu futuro diretor (Figura 8). Como se pode observar, o cânone Beaux-Arts continuava bastante presente nas escolas de arquitetura brasileiras, neste período ${ }^{17}$.

Entretanto, nem sempre era possível a incorporação de tais características nos projetos do período, dada a diversidade de condicionantes de partido a que estavam sujeitos, desde a limitação de verbas - decisiva nos edifícios construídos para renda - até a irregularidade dos lotes centrais,

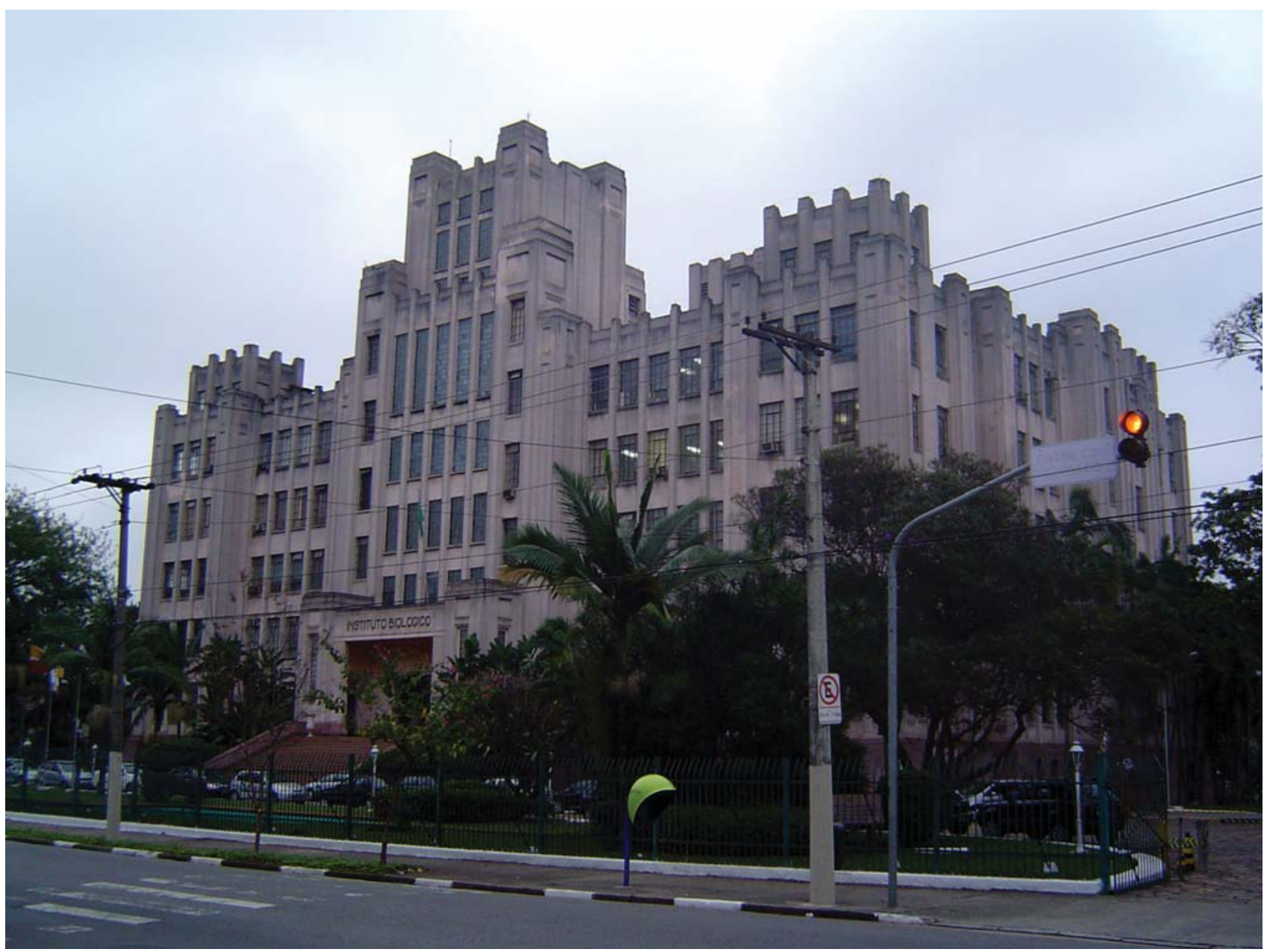

Figura 7 - Instituto Biológico, projetado por Mário Whately. Fotografia de Paulo César Garcez Marins, 2008. 


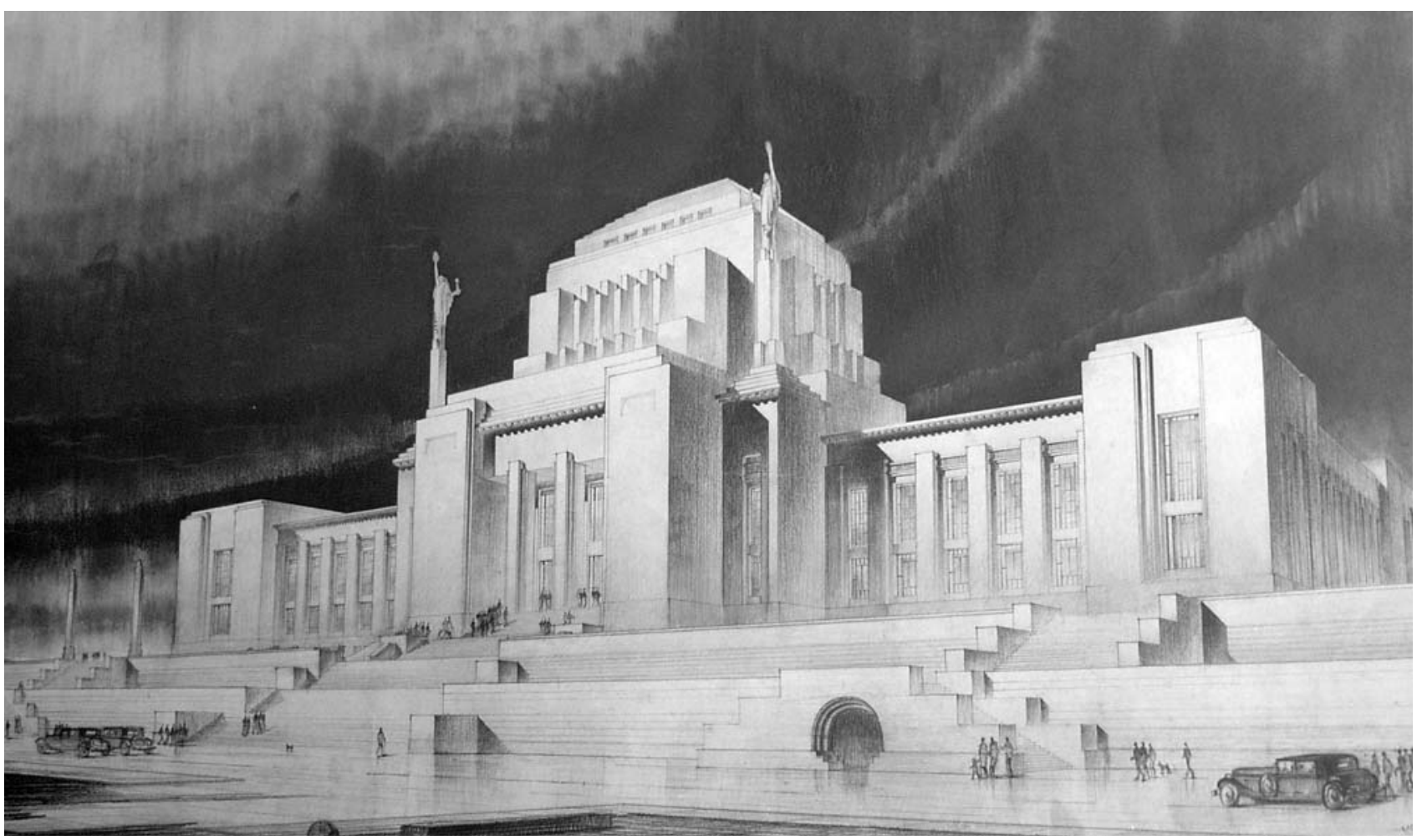

Figura 8 - Palácio para Convenções Rotarianas, projetado pelo aluno Antônio Severo, da ENBA. Acervo do Núcleo de Pesquisa e Documentação da UFRJ. Reprodução de Maria Lucia Bressan Pinheiro, 2003.

determinante em outros casos emblemáticos do Art déco em São Paulo, como o Edifício Saldanha Marinho (1934), no Largo São Francisco - cujo arcabouço estrutural foi concebido por Cristiano Stockler das Neves e completado por Elisiário Bahiana a partir de 192918 -, e o Edifício Banco de São Paulo latual Secretaria Estadual de Esporte, Lazer e Turismo) , situado na praça Antônio Prado e projetado em 1935 por Álvaro Botelho ${ }^{19}$.

Em outros casos, a simetria, embora presente, não é tão enfatizada, e a intenção ornamental recusa os elementos decorativos tradicionais para estender-se à própria volumetria do edifício, através de recursos tridimensionais - balanços, blocos de alturas desiguais, volumes cilíndricos etc. - a sugerir insuspeitado virtuosismo técnico. Um exemplo desta atitude é o Edifício Maria Tereza $^{20}$, Al. Barros, 650, projetado por E. T. de Construções Civis S. Vitale, e o Edifício Buenos Aires ${ }^{21}$, rua Alagoas, 664, do escritório Lindenberg, Alves \& Assumpção (Figuras 9 e 10).

Porém, o aspecto que mais contribuiu para a rápida popularização do Art déco em São Paulo - principalmente na construção de edifícios verticalizados - foi certamente o estabelecimento de uma relação direta entre o despojamento de suas linhas e ornamentos, o apelo de modernidade e o barateamento da construção.
Julio Pinotti, cujo projeto foi publicado em Acrópole (n. 33, jan. 1941, p. 315-320)

10. A esse respeito, deve-se mencionar as dificuldades enfrentadas por Gregori Warchavchik em suas primeiras casas modernistas, conforme relatório enviado a Siegfried Giedion em 1930: "Não tive coragem de construir a casa [da rua Santa Cruz] com cobertura de terraço-jardim, como o teria desejado. Ainda não existiam na praça os materiais isolantes adequados. Cobri o telhado embutido entre as paredes com telhas coloniais".Apud Geraldo Ferraz (1965, p. 51)

11. Ver Acrópole (abr. 1939).

12. Sobre a datação destes edifícios, cabe desde já uma explicação. Excetuando-se aqueles casos excepcionais 


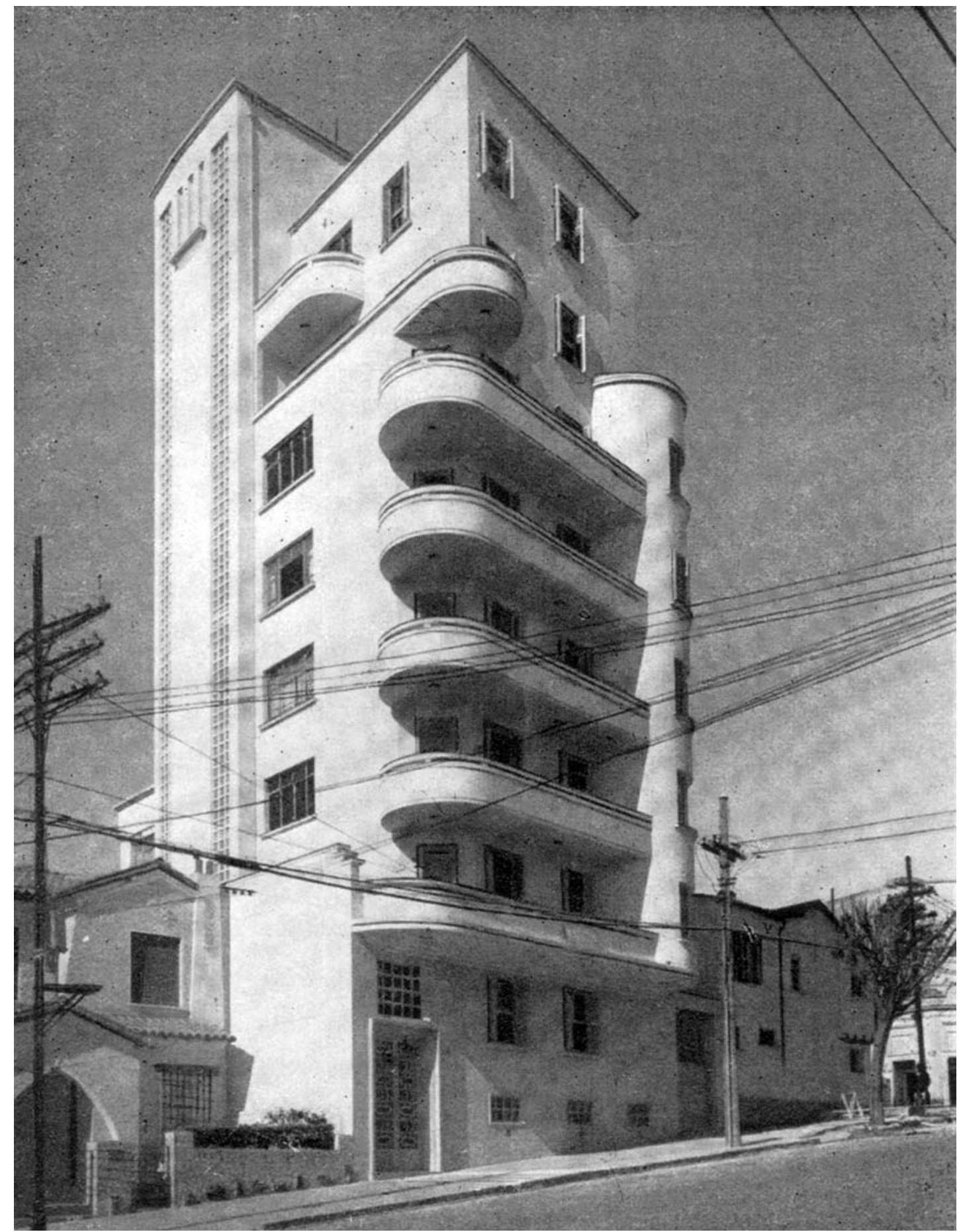

Figura 9 - Edifício Maria Tereza, Alameda Barros. Escritório Técnico de Construções Civis S. Vitale IACRÓPOLE, nov. 1943, p. 198). 


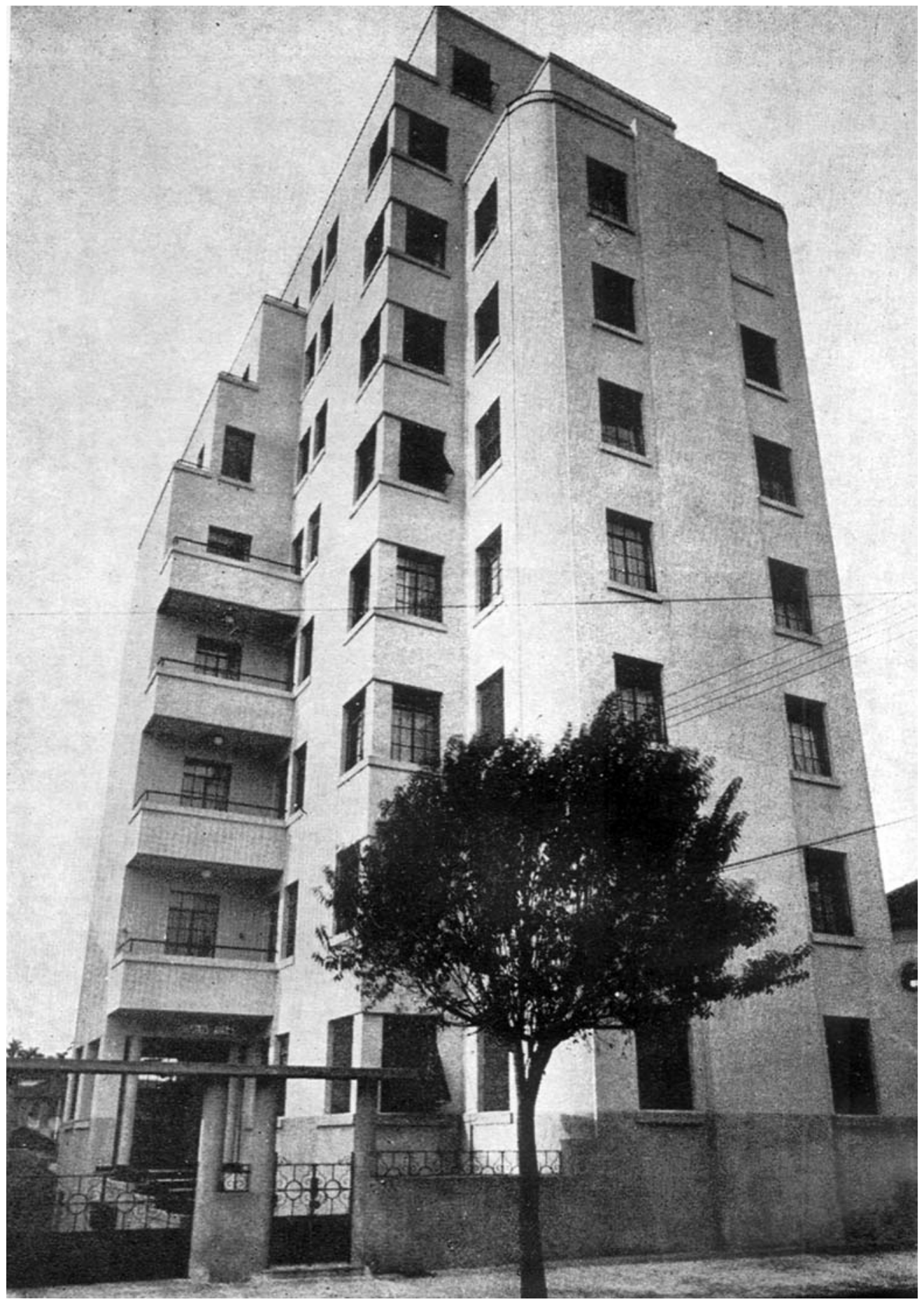

Figura 10 - Edifício Buenos Aires, rua Alagoas. Escritório Lindenberg, Alves \& Assumpção (ACRÓPOLE, set. 1942). 
do proprietário.A dificuldade de obter tais dados previamente à consulta ao processo, bem como a morosidade da tramitação do pedido, levaram-me a optar pela pesquisa na revista Acrópole, a fim de ter contato com uma amostragem quantitativamente significativa da arquitetura paulistana no período em questão.Assim, serão fornecidas aqui apenas as datas em que os edifícios foram publicados na mencionada revista. Da análise dos artigos e das fotografias publicadas, depreende-se que, na maioria dos casos, os edifícios eram publicados pouco tempo depois da conclusão das obras

13.Ver Acrópole (mar. 1940).

14. A descoberta do túmulo de Tutankamon, em 1922, ou a desaparição do Coronel Fawcett - e da expedição enviada para seu resgate - na selva amazônica, em 1925 , são exemplos de acontecimentos cuja grande repercussão na mídia forneceu repertório ornamental para inúmeros projetos Art-déco. A respeito, ver Patricia Bayer (1992).

15. O chamado Método Beaux-Arts de Composição consistia em projetar edifícios ao longo de eixos que se cruzavam no centro do terreno, simetrica e piramidalmente.A respeito, ver David van Zanten (1984)

16. A construção do Instituto Biológico iniciou-se em 1928 , porém só foi concluída em 25.1.1945, data da inauguração oficial do conjunto.Tal morosidade devese à turbulência política e econômica dos anos 1930 , em São Paulo, que causou a paralisação das obras por longos períodos.

17. Nessa entrevista, Memória enfatizava os vínculos acadêmicos da arquitetura então produzida pela ENBA com o classicismo, ao afirmar que procurava "guiar os
Na verdade, apenas o Art déco poderia servir à intenção claramente especulativa da verticalização do centro da cidade nas décadas de 1930 e 1940, já que, por um lado, este estilo representou, de fato, apenas uma atualização dos valores arquitetônicos pré-existentes, sem questioná-los em profundidade; de outro, implicava realmente numa diminuição dos custos da construção, pela diminuição dos ornamentos ou por sua estilização, vale dizer, simplificação.

De fato, no contexto brasileiro do período em estudo, em que o setor da construção civil é totalmente artesanal e poucas são as inovações tecnológicas viáveis, o Art déco possibilitou uma atualização formal que não interferia no canteiro de obras, criando uma imagem de modernidade aparente, que satisfazia os promotores da verticalização sem sacrificar-thes os ucros $^{22}$.

De forma geral, os edifícios residenciais denotam certo apuro no tratamento formal da fachada, no detalhamento do projeto e na especificação dos materiais de acabamento, cuidados necessários para garantir a venda dos apartamentos numa cidade onde, sobre esta forma de morar, ainda pesava a pecha de "cortiços verticais" - como a eles se referiu Yan de Almeida Prado em data tão tardia como 195723. Estas características são mais evidentes em comparação com os prédios de escritórios do mesmo período ${ }^{24}$.

Mas é certamente nas soluções planimétricas que a intenção especulativa de seus promotores revela-se muitas vezes por inteiro, desde os contorcionismos de planta - desenvolvidos para possibilitar o aproveitamento máximo do terreno - até o menosprezo pelos condicionantes técnicos de conforto ambiental (orientação da fachada, ventilação, isolamento acústico etc.). Com raras exceções, tudo se resolvia através da inserção dos famosos poços de ventilação, inóspitos dutos emparedados, que constituem um desafio para a manutenção destes edifícios. Entretanto, por mais insatisfatório que nos pareça hoje, tal expediente denota obediência à legislação sanitária então em vigor: rigorosamente, todos os ambientes dos apartamentos têm aberturas para o exterior.

Por outro lado, precisamente por estas características, os primeiros edifícios residenciais verticalizados podem ser criticados sob muitos pontos de vista, porém nunca pelo convencionalismo das soluções, como veremos.

A esse respeito, um dos primeiros aspectos a destacar é a presença de lojas nos pisos térreos da grande maioria dos edifícios de apartamentos residenciais - diferenciação de uso enfatizada pela presença de marquise e pelo tratamento mais sofisticado conferido a este piso, tanto pela ênfase na entrada principal do edifício - geralmente localizada no eixo de simetria da fachada - como por sua localização dentro do campo visual dos transeuntes.

Assim como o piso térreo em relação à elevação como um todo, também a fachada principal recebia tratamento privilegiado em relação às demais, seja pelo jogo de cheios e vazios, pela maior concentração de elementos ornamentais, ou pelo tipo de revestimento: pedra (em casos excepcionais) ou rebocos especiais, com pó de pedra, adição de mica etc. As elevações secundárias eram revestidas com reboco simples, configurando uma nítida hierarquização de fachadas. 
É igualmente evidente a preocupação em ocupar toda a área possível do terreno, independentemente de sua orientação - e, portanto, de suas condições de insolação. Por outro lado, a análise das plantas desses edifícios demonstra que, nas décadas de 1930 e 1940, o programa habitacional verticalizado, e portanto sua clientela, encontrava-se ainda indefinido. Praticamente todos os edifícios apresentam apartamentos de diferentes tamanhos, inclusive no mesmo andar, o que - além de facilitar o desejado aproveitamento máximo do lote sugere a experimentação de soluções variadas, na busca de atender às expectativas ainda desconhecidas de um novo mercado.

Com relação às dimensões variáveis dos apartamentos, deve-se mencionar que as diferenças não se explicam apenas pelo maior ou menor número de dormitórios, como ocorre hoje em dia. Com freqüência são encontrados apartamentos com apenas um dormitório, mas com sala de visitas e sala de jantar indicados em planta, por exemplo; ou unidades de dois ou mais dormitórios, e apenas uma sala indicada em planta. Os corredores internos são empregados com parcimônia, para resolver os intrincados esquemas de circulação decorrentes da utilização máxima da área do terreno, e não para garantir às unidades o zoneamento doméstico tradicional em áreas de estar, repouso e serviço.

Em comparação com os programas residenciais unifamiliares do mesmo período, a característica programática mais inusitada desta arquitetura é a inexistência de cozinhas, verificada em número significativo de apartamentos residenciais desse período. Quais os expedientes então utilizados para prescindir de uma cozinha doméstica? Só podemos imaginar: restaurantes, pensões, etc. ${ }^{25}$. Apenas estudos histórico-sociológicos sobre a vida em São Paulo neste período poderão contribuir para iluminar esta questão, para a qual muitas vezes invocamse propósitos maliciosos: tratar-se-ia das famosas garçonières, tão mencionadas em memórias e depoimentos ${ }^{26}$. $\bigcirc$ que é mais surpreendente - inclusive a levarse em conta tal explicação - é a existência de tais unidades misturadas a apartamentos de programa familiar completo, não só no mesmo prédio, como também no mesmo andar - como ocorre no edifício Lívia Maria, como veremos.

Áreas de serviço e respectivos tanques nem sempre se encontram claramente configurados, sendo lícito supor que os terraços posteriores dos apartamentos eram utilizados como tal. Sabemos que nas moradias brasileiras foi muito comum o expediente de encarregar a lavagem doméstica de roupas a lavadeiras avulsas - "lavar roupa fora", dizia-se; porém é surpreendente pensar que, em cidades do porte de São Paulo, tal hábito tenha perdurado pelas décadas de 1930 e 1940.

Alguns poucos edifícios foram projetados com equipamentos coletivos, mas sabemos que tais hábitos não chegaram a implantar-se com sucesso na cidade - talvez por serem associados aos tanques, latrinas e cozinhas coletivos, típicos dos cortiços do início do século. É o caso do Edifício João Alfredo (rua das Palmeiras 107), que foi projetado com lavanderia coletiva, conforme publicado em Acrópole ${ }^{27}$ (Figuras 11 a 13).

Outro aspecto no qual se percebe claramente o caráter ensaístico das soluções é a previsão, ou não, de quartos de empregada para cada unidade, passos de seus alunos mediante o conhecimento das três principais expressões da arquitetura ocidental: neogrego, românico e ogival", pois, "com tais conhecimentos estão os alunos aptos a darem expansão às suas emoções com um senso lógico, dentro do equilíbrio das proporções clássicas". O projeto de Antônio Severo aliás filho do engenheiro português Ricardo Severo está reproduzido no artigo, "para corroborar e ilustrar" as palavras de seu professor. Apud Maria Lúcia Bressan Pi nheiro (2005, p. 68-69).

18. A despeito da importância e da visibilidade do edifício, persistem muitas dúvi das acerca da história de sua construção, inclusive da data do projeto inicial de Stoc kler das Neves, que teria sido vencedor em um concurso público promovido pelo Automóvel Club de São Paulo. Ver Vitor José Baptista Campos (1996, p. 241)

19. O edifício é composto por dois corpos distintos, com testada para rua Quin ze de Novembro-praça An tônio Prado e para a rua São Bento, um agenciamento re sultante da junção de vários lotes irregulares; $a$ interligação entre os blocos é feita por corredores adjacentes às divisas do lote, ao redor do poço de ventilação/iluminação.A despeito da irregularidade do volume, a composição da fachada principal desenvolve-se a partir de eixo de simetria claramente demarcado, e enfatizado por sofisticada ornamentação. Como diz Vítor Campos (1996, p. 235), "pelo menos no caso desse edifício, modernização não foi interpretada como sinônimo de economia e despojamento".

20.Ver Acrópole (nov. 1943).

21. Idem, set. 1942.

22. As palavras de Luís Villares não deixam margem a dúvidas:"Um projeto moderno 


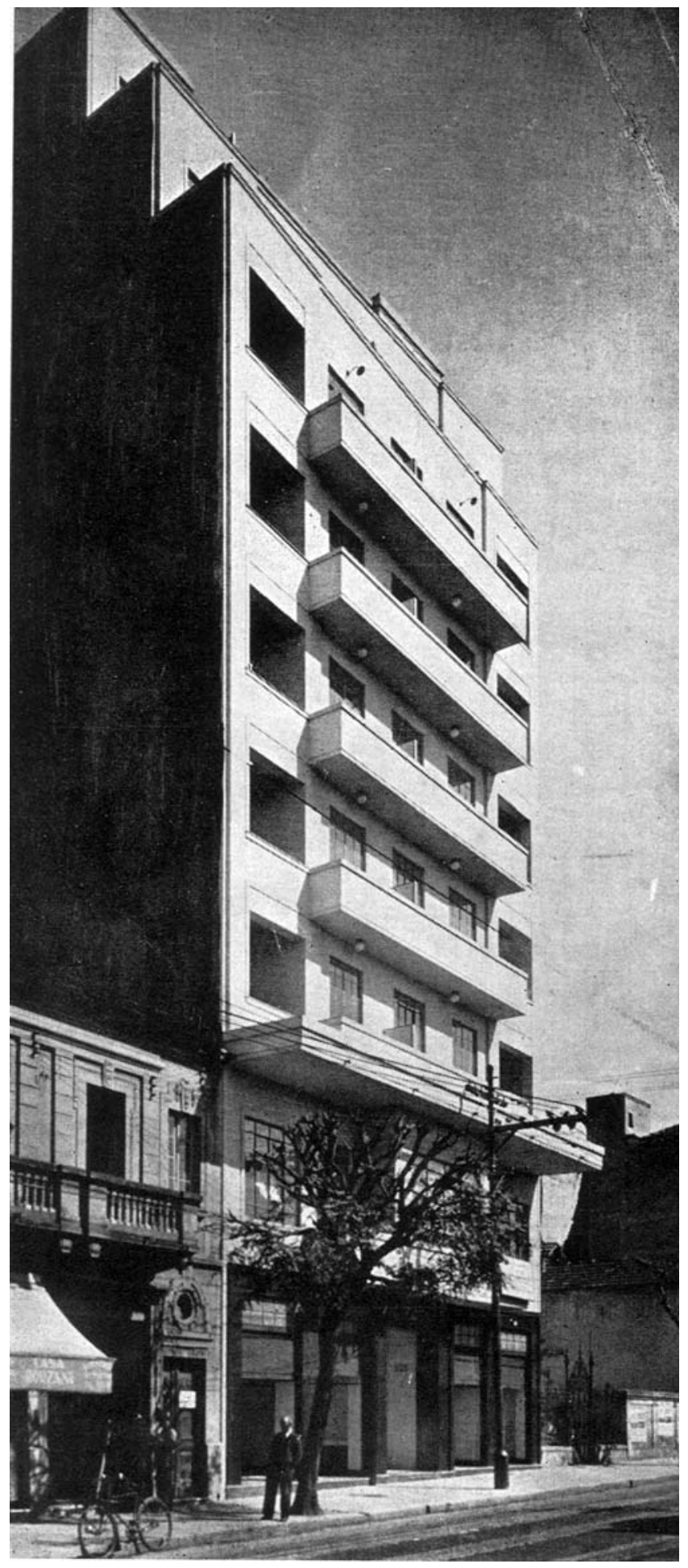

Figura 11 - Edifício João Alfredo, rua das Palmeiras, 107 (ACRÓPOLE, set. 1942, p. 173).

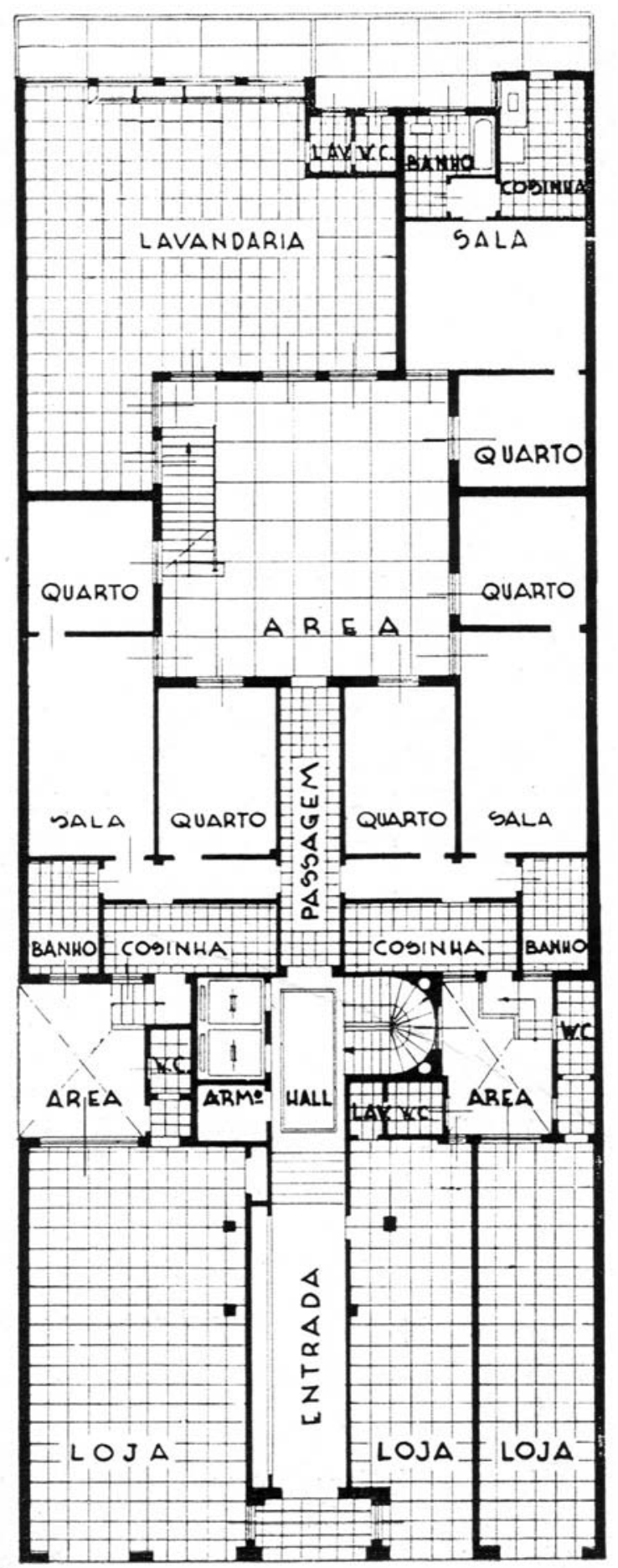

Figura 12 - Piso térreo do Edifício João Alfredo, projetado com lavanderia coletiva pelo Escritório Moya \& Malfatti (ACRÓPOLE, set. 1942, p. 173). 


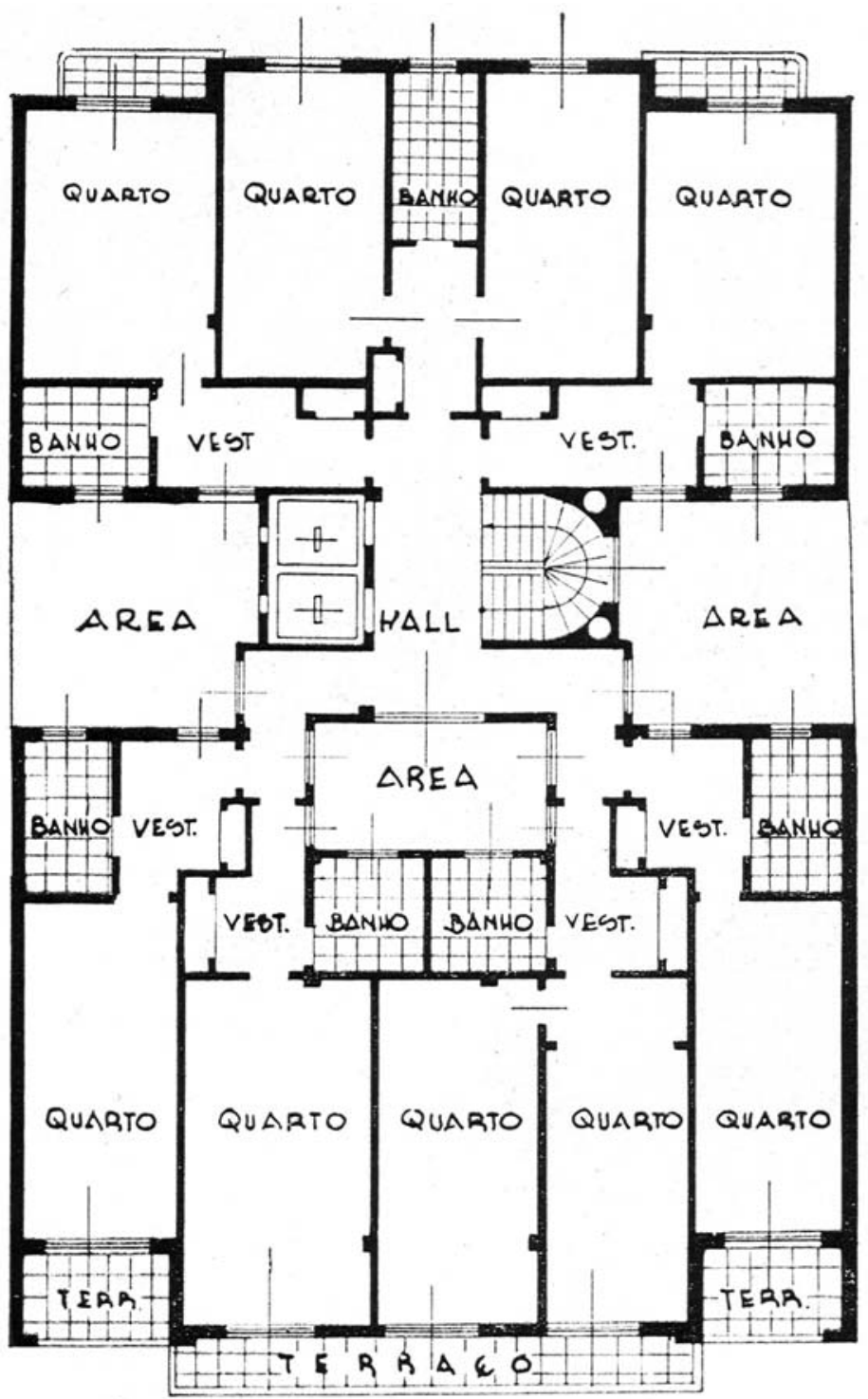

PLANTAS DO 2:.3:,4:,5 e 6: $\triangle N D A F$

Figura 13 - Pavimento-tipo do Edifício João Alfredo (ACRÓPOLE, set. 1942, p. 174)

e sua localização. Parece ter sido mais comum do que se poderia esperar a inexistência de quaisquer dependências para empregadas domésticas nos edifícios, o que, se é facilmente explicável no caso daqueles apartamentos sem cozinha, não deixa de surpreender, numa sociedade tão fortemente dependente da mão-de-obra doméstica até os dias de hoje. Assim, é plausível especular sobre a impossibilidade do público-alvo destes apartamentos contratar empregados desse tipo ${ }^{28}$. geralmente não é mais caro, e sempre traz, pela admiração que causa, maior prestígio para a empresa". Apud Nadia Somekh (1994, p. 172). Sobre a acepção da palavra 'moderno' no contexto da época, ver Maria Lúcia B. Pinheiro (2001).

23. Cf. Yan de Almeida Prado (1960, p. 25.).

24.A respeito, ver o capítulo 3 de Maria Lúcia Pinheiro (1997, p. 121-201).

25. Segundo Carlos Lemos, o primeiro prédio de apartamentos residenciais de São Paulo (rua Líbero Badaró esquina com rua Dr. Falcão), projetado por Samuel das Neves por volta de 1916 , apresentava "apartamentos de sala, quarto e banheiro para homens solteiros ou viúvos, que tomavam as refeições nos restaurantes das proximidades" (1976, p. 161). Mas, na visão do autor, este seria um caso excepcional; na mesma obra, ele enfatiza que os primeiros edifícios residenciais paulistas "deveriam ter cozinha, tanque, banheiro e quarto de criada, pois toda família que se prezava tinha uma empregada morando em casa" (1976, p. 162).

26. A comprovar-se tal explicação, a verticalização residencial de São Paulo estaria em boa parte a serviço de amores ilícitos... Talvez a famosa garçonière de Oswald de Andrade, na avenida São João, tenha inspirado tais comentários. Uma pesquisa complementar nos anúncios imobiliários relativos a estes edifícios, nos moldes daquela realizada por Lílian Fessler Vaz nos jornais do Rio de Janeiro, poderia trazer respostas a estas dúvidas. No caso carioca, os anúncios mencionavam as diversas possibilidades disponíveis aos locatários: "moradia como ou sem refeições, com ou sem café da manhã, com ou sem mobília,com ou sem cozinha [...] Em alguns casos o ser- 
viço de hotelaria desaparecia sem que os apartamentos fossem dotados de cozinha; geralmente, nesses casos havia um restaurante no próprio prédio ou nas proximidades" - como no anúncio, publicado no Jornal do Comércio (18 mar.1928), do edifício Esplanada, àAv. Mem de Sá, 253, cujos apartamentos poderiam ser servidos "pelo luxuoso restaurante Esplanada aberto dia e noite”. Cf. Lílian Fessler Vaz (1994, p. 103).

27. Ver Acrópole (set. 1942).

28. Tal hipótese já foi aventada por Carlos Lemos (1976), embora o autor não mencione a inexistência de cozinhas em número significativo de apartamentos paulistas.

29. A mesma solução é encontrada em exemplares do Rio de Janeiro. Ver Luiz Paulo Conde (1988) e Lílian Fessler Vaz (1994).

30. Trata-se do primeiro edifício listado no inventário de Arquitetura Moderna Paulistana. Ver Corona, Lemos \& Xavier (1983).

31.A pesquisa sugere que, no caso de São Paulo, a existência de uma rígida separação entre entrada principal e entrada de serviço tornar-se-á usual a partir da construção dos edifícios em condomínio; é uma hipótese, porém, que carece de confirmação.
Nas unidades que contavam com quartos de empregada, uma solução que parece ter sido razoavelmente comum foi a concentração de todas as dependências de empregada (quartos e banheiros) no último pavimento do prédio - uma solução provavelmente inspirada nos andares de chambres-debonne parisienses, normalmente a mansarda dos prédios, ou ainda numa radicalização da segregação típica da casa grande e senzala... Tal solução, bastante disseminada no período ${ }^{29}$, foi empregada no edifício Regência (Figura 18), e também no edifício de apartamentos projetado em 1927 por Júlio de Abreu Júnior (avenida Angélica) ${ }^{30}$, entre outros.

Por outro lado, tais características segregacionistas são menos usuais do que seria de esperar. Na grande maioria dos edifícios pesquisados, por exemplo, não há entrada de serviço no nível térreo, ainda que elas sejam encontradas em boa parte dos apartamentos. Em alguns casos - geralmente prédios mais baixos - inexistiam até mesmo elevadores de serviço ${ }^{31}$.

Como ocorria nas residências do período, todos os apartamentos residenciais, por menores que fossem, contavam com banheiros privativos - ao contrário dos edifícios comerciais, onde eram usuais os banheiros coletivos. Entretanto, os lavabos - onipresentes nas residências unifamiliares, invariavelmente colocados sob as caixas de escada - são absolutamente inexistentes nos apartamentos residenciais desse período.

Ainda a respeito do programa, é interessante acompanhar a previsão ou não de garagens para os automóveis dos moradores dos prédios residenciais. Uma das soluções mais usuais reservava determinado número de vagas - para as quais se construía uma cobertura bastante simples, de telhas onduladas - nos fundos do lote, em nível, como ocorre no Edifício Higienópolis e no Edifício Santa Amália. A solução mais sofisticada era, certamente, a construção de garagens subterrâneas, existentes no Edifício Esther e em alguns edifícios residenciais construídos no centro novo de São Paulo, como o já mencionado Edifício Regência e o Edifício Maria Paula, ambos do engenheiro-arquiteto Arquimedes de Barros Pimentel. Entretanto, o número de vagas disponíveis era sempre muito inferior ao número de apartamentos do edifício.

A presença de garagens, já bastante rara nos prédios de apartamentos residenciais, era absolutamente fora de cogitação para os edifícios comerciais - o que hoje constitui problema a ser superado para a desejada revitalização da área central de São Paulo, maciçamente verticalizada a partir de 1930.

Tais são as características genéricas da arquitetura residencial verticalizada em São Paulo, no período, como uma consulta, mesmo aleatória, à revista Acrópole pode comprovar. A título de ilustração, passaremos a seguir à análise de alguns casos específicos, emblemáticos dos aspectos levantados até aqui: os edifícios Lívia Maria, Regência, Dona Veridiana e Santa Amália. Devido a sua grande diversidade, eles podem ser tomados como uma síntese da variação de plantas e do perfil de moradores dos edifícios publicados naquele periódico. 
Edifício Lívia Maria, na avenida São João esquina com rua Timbiras, projetado pelo escritório H. S. Caiuby, constitui um dos mais característicos projetos de apartamentos residenciais daqueles anos. Com franqueza pouco usual nos dias de hoje, seus autores, em artigo publicado em Acrópole, admitem que "procuraram para a obra a maior simplicidade possível de linhas, obedecendo assim a sua finalidade, isto é, o edifício para renda" ${ }^{32}$. Trata-se de edifício de 11 andares, construído em lote irregular de esquina, sem recuos frontais ou laterais (Figura 14). A volumetria do edifício tira partido de trechos de fachada em balanço, associados aos balcões curvos, tão usuais no período - como veremos, solução já indicada no Edifício Columbus (ca. 1933) (Figura 29) e plenamente desenvolvida no Edifício Wancolle (1935) ${ }^{33}$, projetos residenciais de Rino Levi, infelizmente já desaparecidos, por demolição (caso do Columbus) ou por descaracterização (caso do Wancolle, rua do Arouche, 153, ainda de pé mas absolutamente irreconhecível). No Lívia Maria, o ângulo da fachada foi suavizado em curva, e enfatizado por largos frisos horizontais, bastante característicos desta arquitetura.

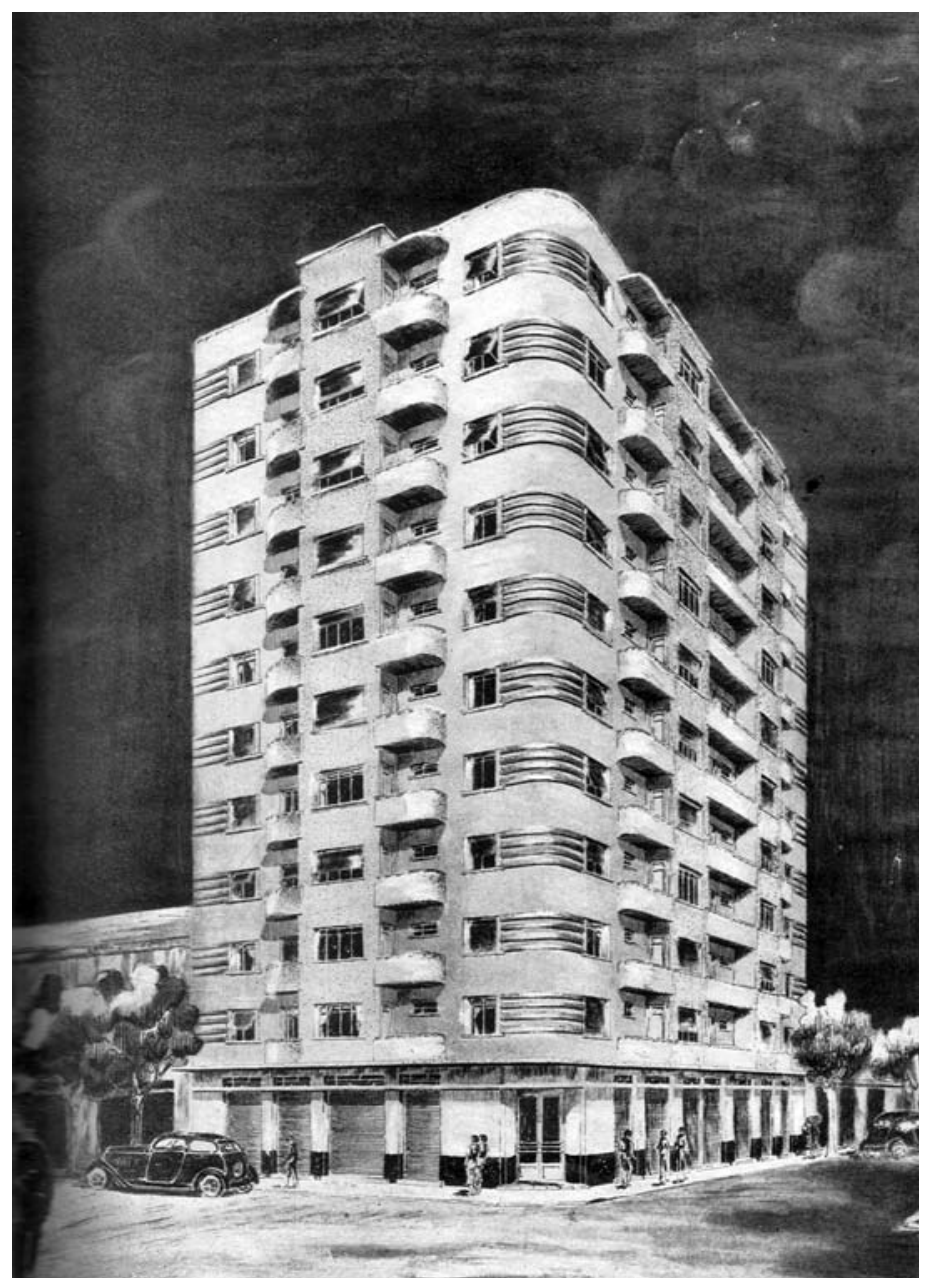

Figura 14 - Perspectiva do Edifício Lívia Maria, avenida São João com rua Timbiras. Escritório H. S. Caiuby (ACRÓPOLE, mai. 1938, p. 53). 
Como era usual, o pavimento térreo - claramente destacado da fachada por marquise - tem uso comercial; as três lojas previstas ocupam quase todo o terreno, excetuando-se uma área no fundo, onde localizam-se três WCs, um para cada loja. A entrada única dá-se em ângulo a partir da esquina, conduzindo ao hall de acesso aos demais pavimentos (Figura 15).

andar-tipo compõe-se de 5 apartamentos, resolvidos segundo nada menos do que 3 tipologias diferentes (Figura 16): uma composta por sala, quarto e banheiro (3 unidades); outra com sala de jantar, 2 quartos, cozinha e banheiro; e, finalmente, a unidade de maior área, com sala de estar, sala de jantar, 2 quartos, cozinha e banheiro. Todos os apartamentos são dotados de terraços, que parecem funcionar também como áreas de serviço; em nenhum constam dependências de empregada ou entrada de serviço, mas há chuveiro e WC coletivo em cada andar.

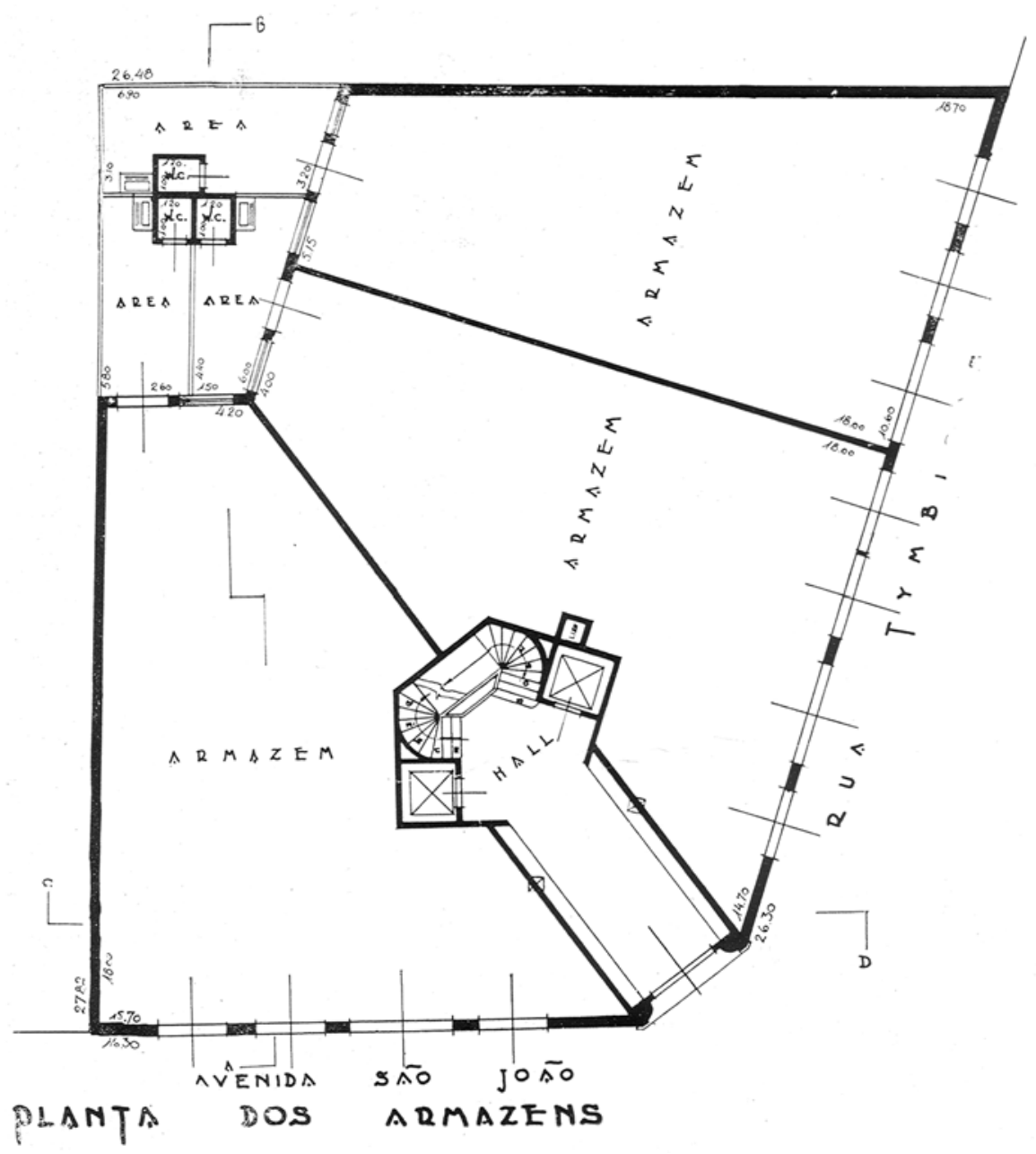

Figura 15 - Piso térreo do Edifício Lívia Maria (ACRÓPOLE, mai. 1938, p. 52). 


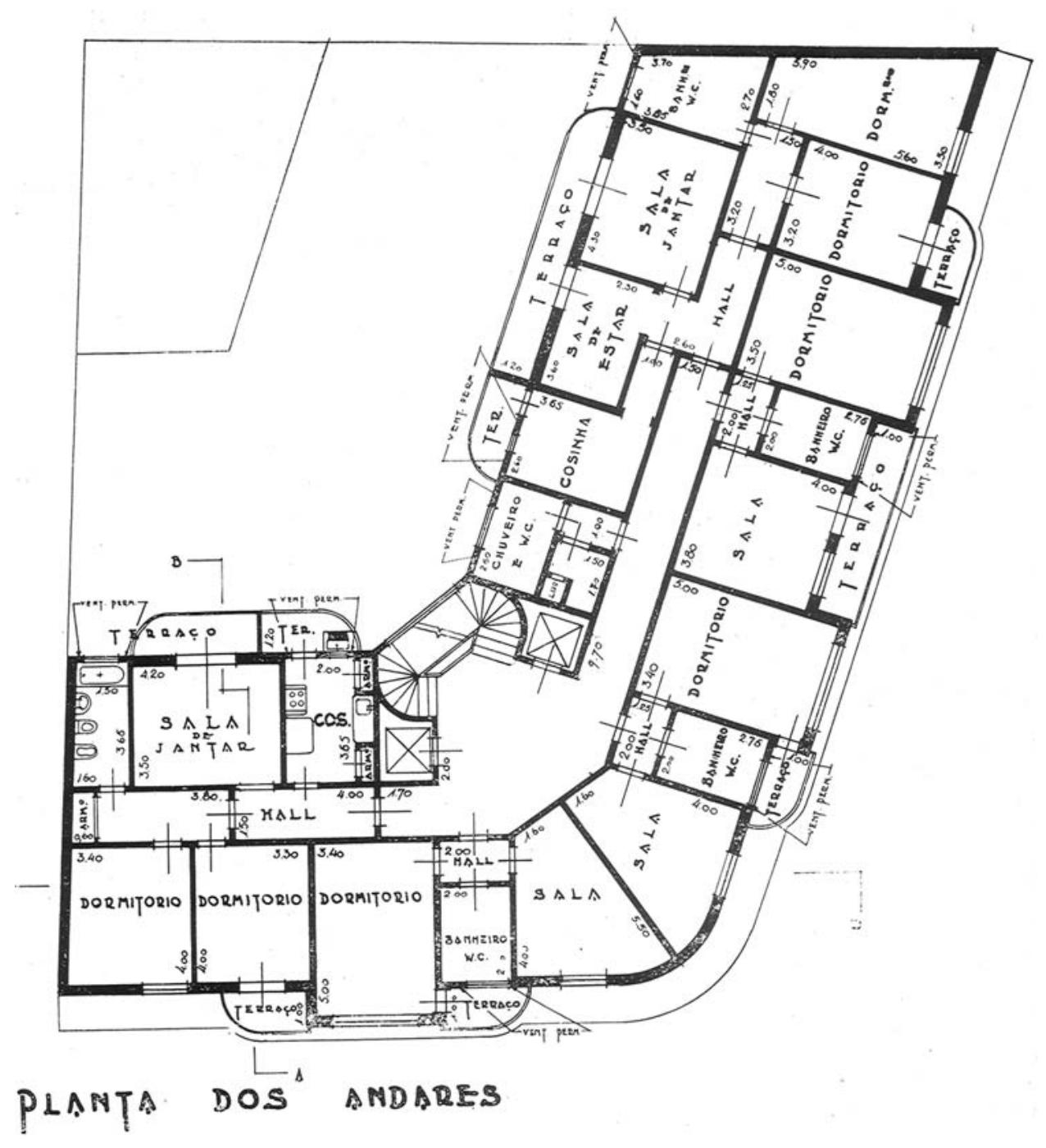

34. Ver Acrópole (jun. 1940).

Figura 16 - Pavimento-tipo do Edifício Lívia Maria (ACRÓPOLE, mai. 1938, p. 52).

Face a tal diversidade de agenciamentos, é difícil imaginar como seria a convivência entre moradores de unidades tão díspares entre si: famílias inteiras, com crianças e, certamente, empregadas domésticas, ainda que diaristas; moços solteiros (estudantes? comerciários?) nos apartamentos sem cozinha, obrigados a fazer suas refeições em restaurantes ou pensões.

O Edifício Regência (1939), rua Xavier de Toledo esquina com Rua Sete de Abril, projetado pelo engenheiro-arquiteto Arquimedes de Barros Pimentel, também foi implantado sem recuos, em lote de esquina bastante irregular, como se vê em Acrópole ${ }^{34}$ (Figura 17). Contudo, apresenta algumas soluções inovadoras 


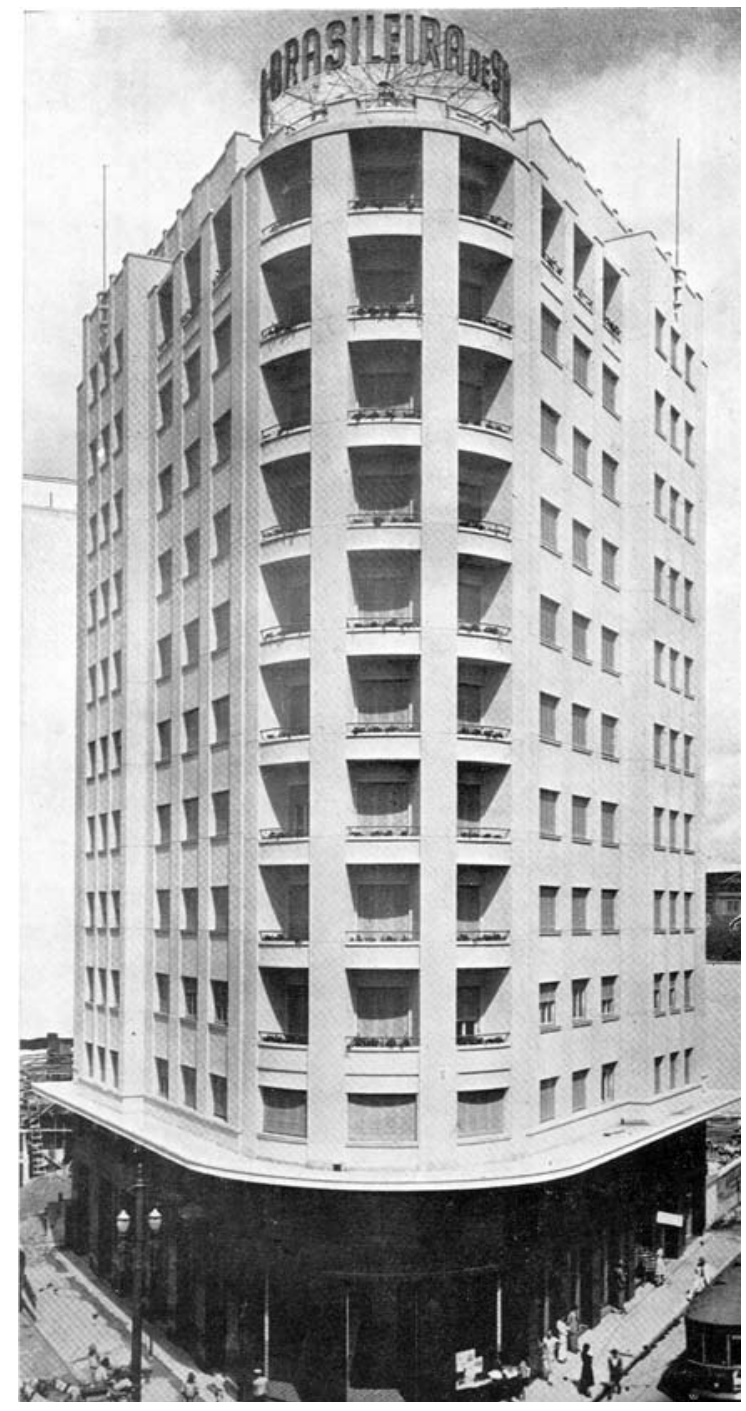

Figura 17 - Edifício Regência, rua Xavier de Toledo com rua Sete de Abril, projetado pelo engenheiro-arquiteto Arquimedes de Barros Pimentel (ACRÓPOLE, jun. 1940, p. 79).
35. Em que pese a desproporção entre o número de apartamentos e o de vagas oferecidas, trata-se de solução pioneira para a época, também presente no Edifício Esther.

36. Sobre a arquitetura residencial unifamiliar, ver o capítulo 2 de Maria Lúcia B. Pinheiro (1997, p. 57-120). Quanto à existência de falsas lareiras nos edifícios pesquisados, além do Regência, foi possível identificar sua presença apenas no Edifício $S$. José.Ver Acrópole (n. 40,p. 161-168, 1940). para a época, como a construção de garagem subterrânea - 14 vagas para 40 apartamentos $^{35}$ - e a relativa uniformidade dos programas das 4 unidades residenciais de cada piso, cujas diferenças residem no número de dormitórios, que variam de 2 a 3 por apartamento (Figura 18). Em termos de solução projetual, cabe destacar a integração espacial da sala de visitas e sala de jantar, ensaiada numa das duas tipologias existentes em cada andar do edifício. Também é digna de nota a previsão de falsas lareiras - equipamento bastante usual nas residências unifamiliares de classe média do período ${ }^{36}$ - nas salas de todos os apartamentos (Figura 19). Tais requintes de acabamento, aliados à existência de apartamentos de 3 dormitórios, configuram o Regência como um empreendimento voltado a uma classe social mais abastada do que a da maioria dos edifícios residenciais contemporâneos, em que predominavam unidades de até 2 dormitórios. 

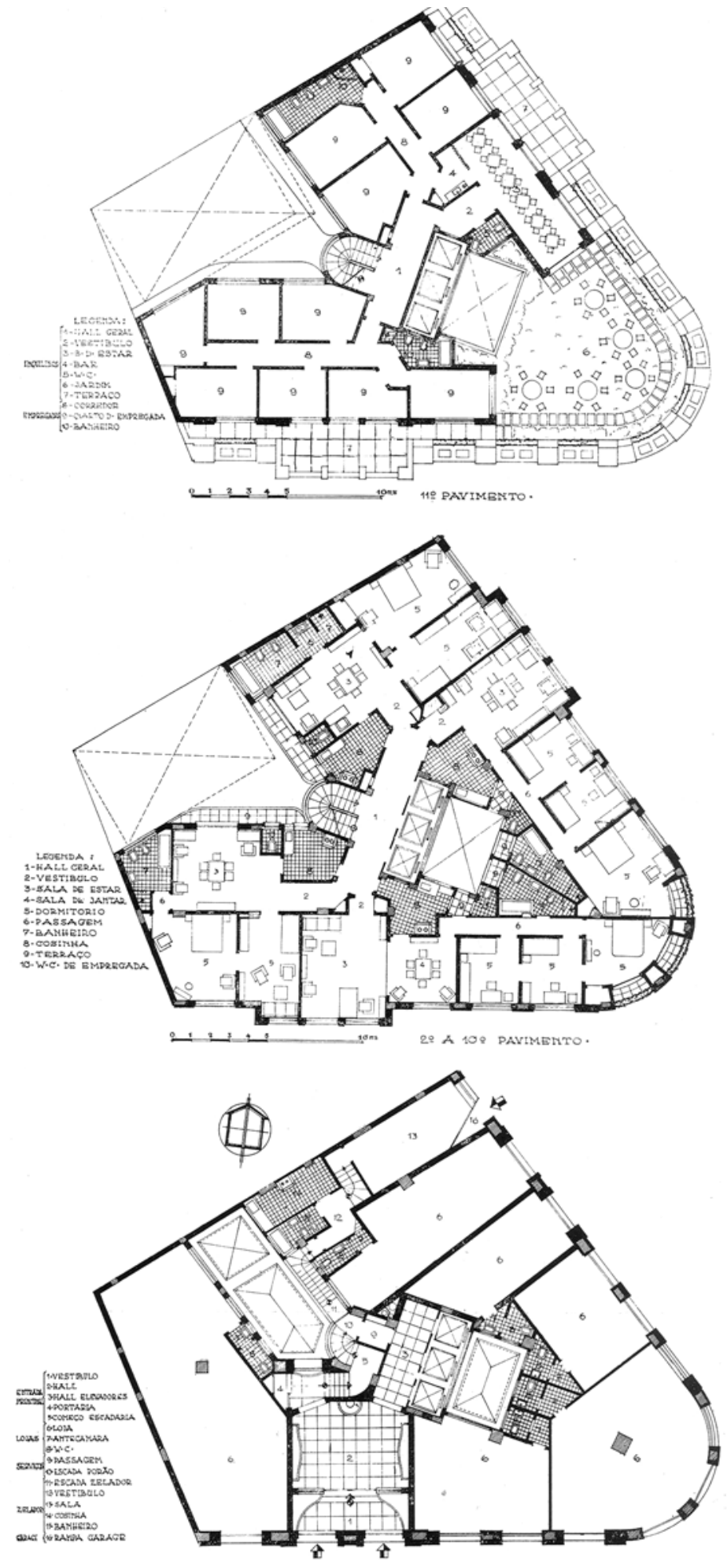

80
Figura 18 - Edifício Regência, plantas do pavimento térreo, dos andarestipo e da cobertura (ACRÓPOLE, jun. 1940, p. 80). 


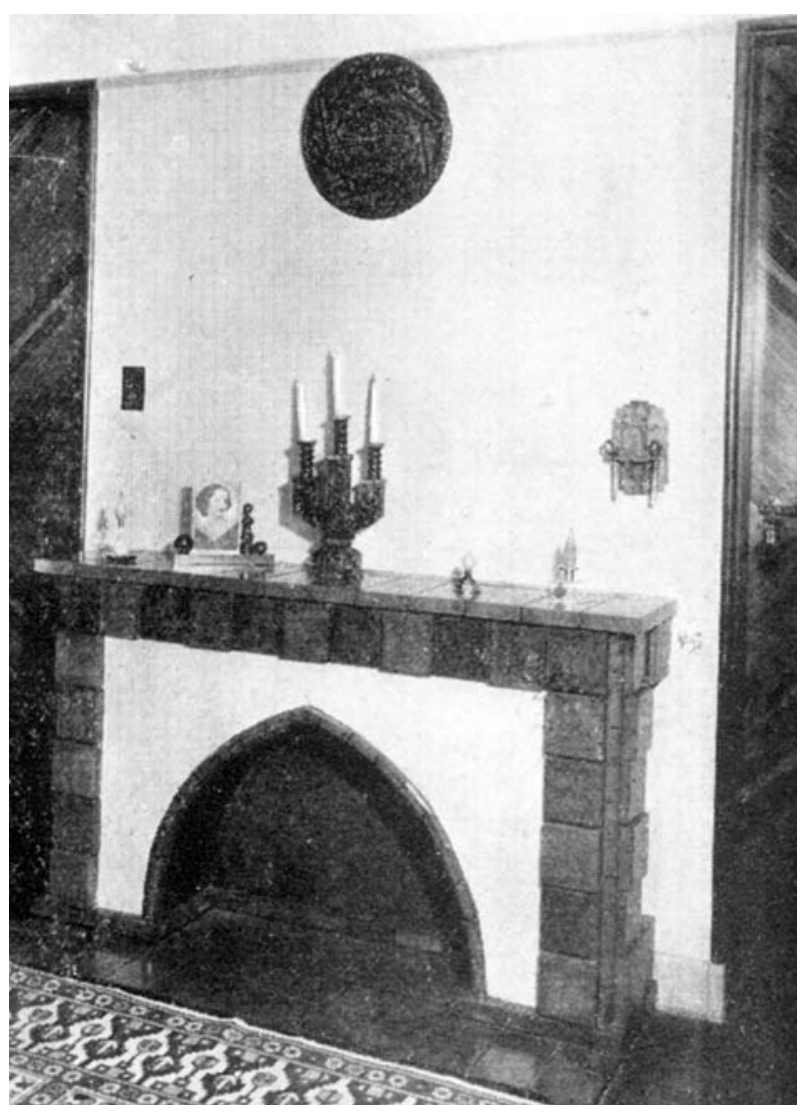

Figura 19 - Um dos modelos de lareira presentes em um dos apartamentos do Edifício Regência (ACRÓPOLE, jun. 1940, p. 86).

Neste edifício, todos os apartamentos possuem WC e entrada de serviço, mas as dependências de empregada propriamente ditas estão concentradas no último andar, onde também foram previstos bar e jardim para uso coletivo dos moradores - algo diverso, portanto, dos terraços-jardim privativos dos apartamentos de cobertura (Figura 20). Funcionando como áreas de serviço, há terraços posteriores ou pequenas áreas contíguas às cozinhas e banheiros.

Formalmente, o exterior do edifício é bastante despojado, inclusive quanto à volumetria; a ênfase reside no trecho curvo da fachada, com terraços reentrantes que criam interessante jogo de luz e sombra. Destaque para o grande anúncio que coroa o corpo central do edifício, assumindo papel ornamental de signo de modernidade. Não são aí encontrados nenhum dos recursos característicos da arquitetura modernista, como janelas contínuas, ou pilotis, por exemplo - ainda que parte da cobertura seja um terraço-jardim, como vimos. $\bigcirc$ piso térreo - ocupado por lojas, como de costume - recebe tratamento nobre: revestimento em granito negro polido, e luminárias francamente Art déco (Figura 21). No hall do edifício as características Art déco se acentuam, mediante o uso decorativo de granitos, mármores e espelhos, bem como de um nu feminino de Giusti, que preside o ambiente. Cabe destacar a inexistência de entrada de serviço. Outra particularidade é que o 1. andar destinava-se a escritórios, a 


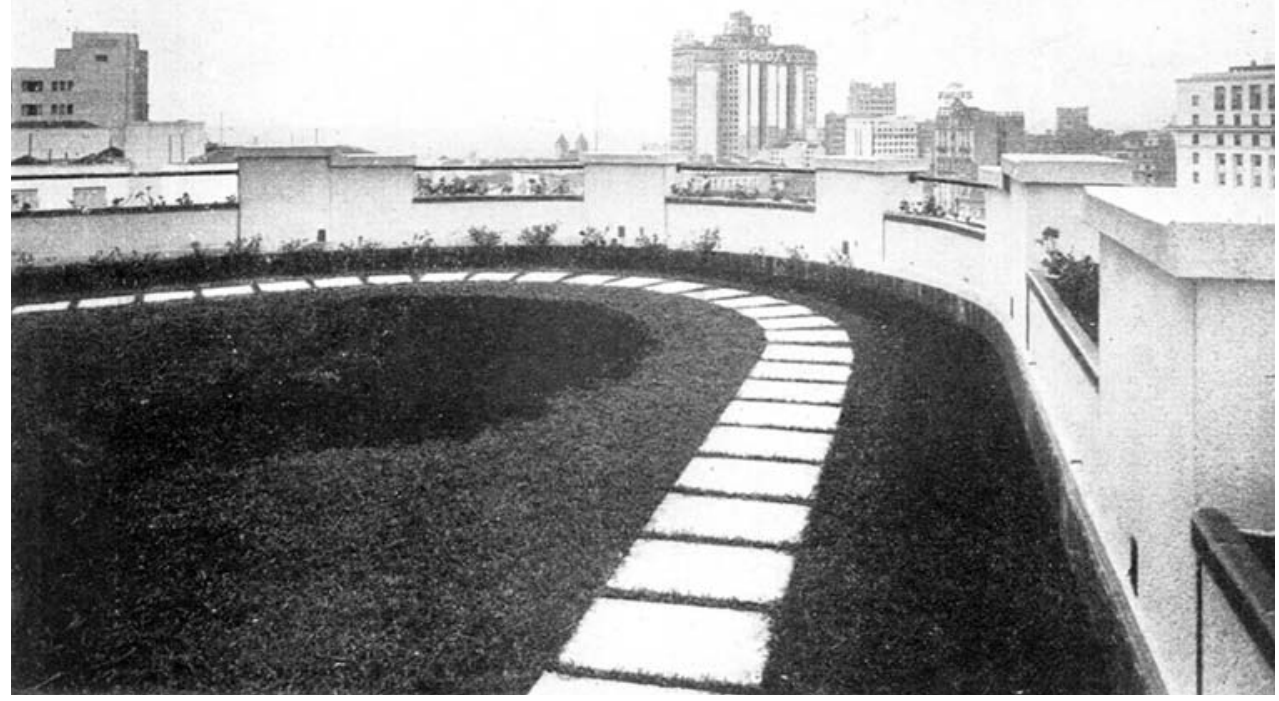

Figura 20 - Vista do $11 \%$ pavimento (cobertura) do Edifício Regência (ACRÓPOLE, jun. 1940, p. 83)

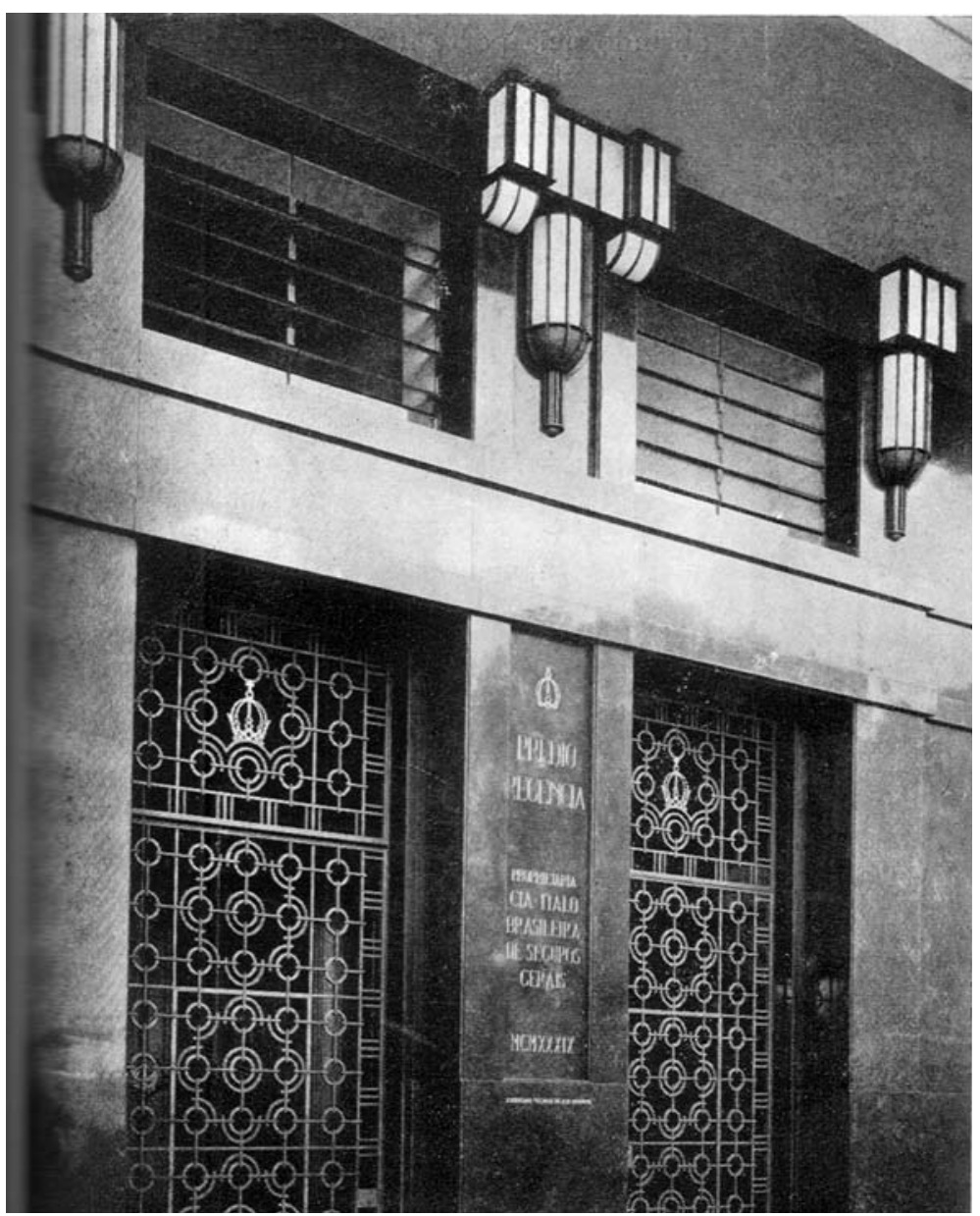

Figura 21 - Vista externa da entrada principal do Edifício Regência (ACRÓPOLE, jun. 1940, p. 81 ). 
serem alugados preferencialmente aos moradores - agenciamento também previsto no Edifício Esther.

Prédio Dona Veridiana (rua Martinico Prado, 25), projetado por Francisco Beck ${ }^{37}$, constitui um exemplo sui-generis no quadro estudado (Figura 22). Trata-se de um edifício mais baixo 16 andares, contra mais de 10 nos demais edifícios), com apenas 16 unidades; mesmo assim, conforme o andar, identificamse 4 diferentes tamanhos de apartamento. No térreo - que é destacado do restante da fachada pela indefectível marquise, apesar da inexistência de lojas -, encontramse 2 apartamentos de 2 salas e 1 quarto, cozinha e banheiro; do 2. ao 4. andar, 3 unidades, também com 2 salas e 1 quarto, cozinha e banheiro - mas seguindo disposições planimétricas pouco funcionais, como se vê na figura 23. No 5. andar localizam-se apartamentos maiores (2 unidades), de 2 salas e 2 quartos, além de cozinha e banheiro - nos quais, a despeito de sua maior área, continua evidente a despreocupação quanto ao agrupamento dos cômodos em uma zona social,

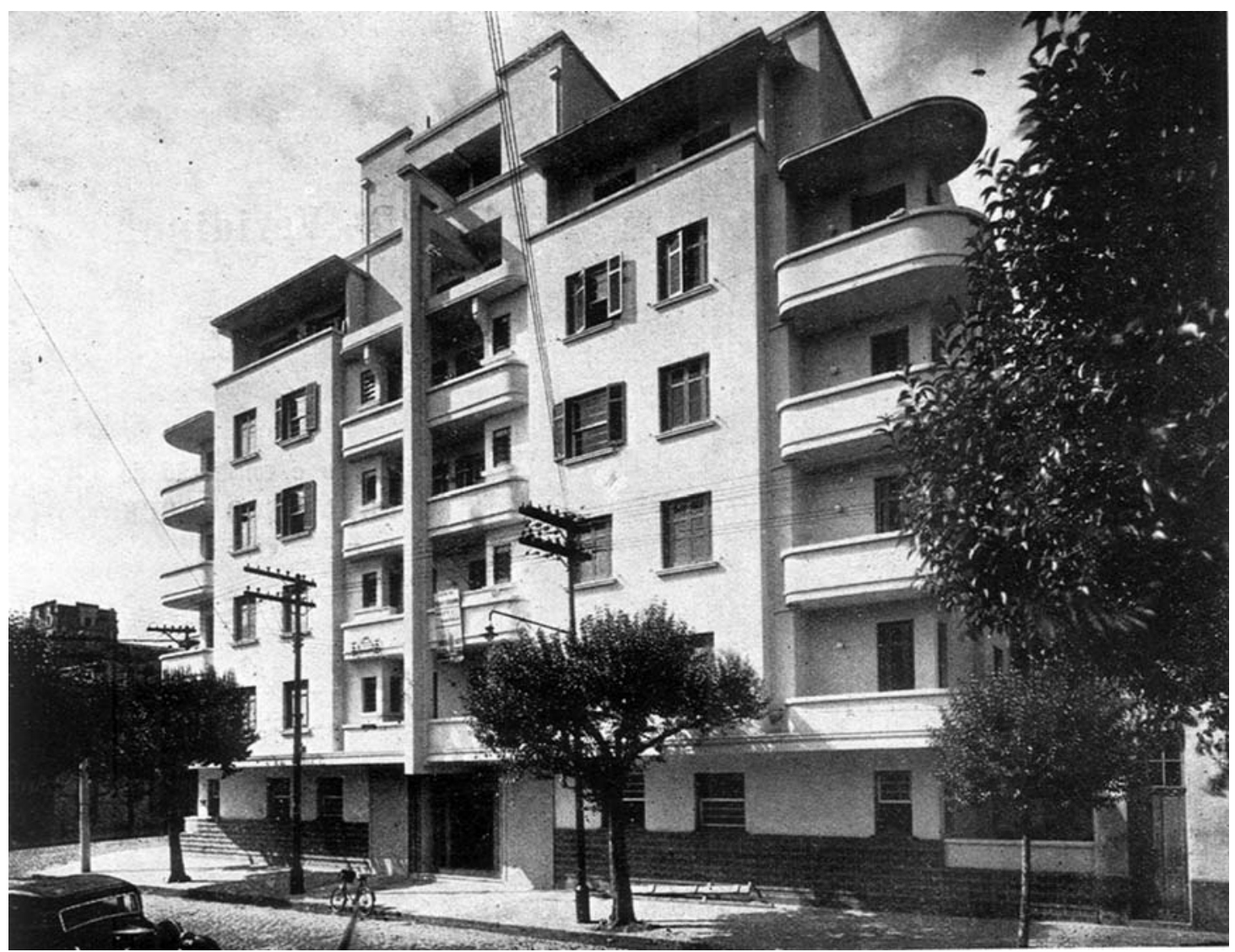

Figura 22 - Prédio Dona Veridiana, rua Martinico Prado, projetado por Francisco Beck (ACRÓPOLE, Nov. 1941, p. 279). 


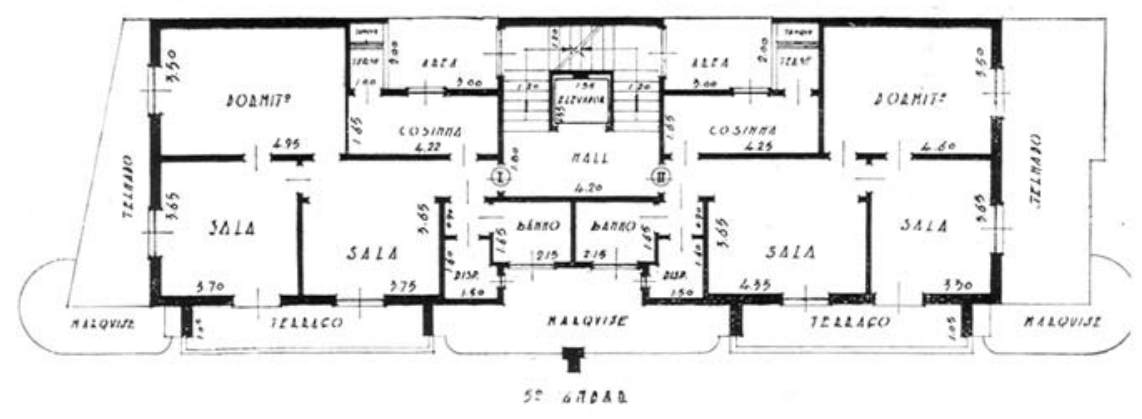

38. A mesma solução é encontrada também no Edifício Amália (rua Xavier de Toledo.250), projeto de Taddeu Giuzio.Ver Acrópole (n. 22, p. 41-44, fev.1940).
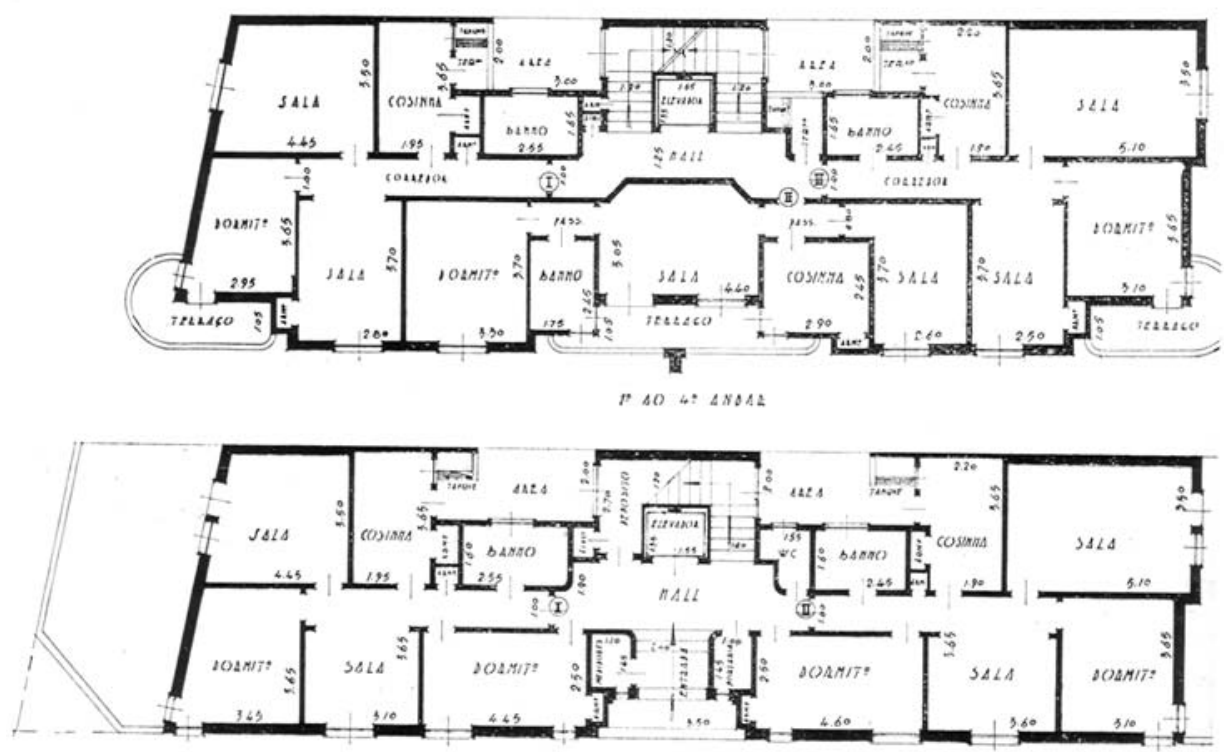

Figura 23 - Plantas do térreo, do pavimento-tipo e da cobertura do Prédio Dona Veridiana (ACRÓPOLE, Nov. 1941, p. 279).

uma de repouso e uma de serviço. Não há dependências para empregadas nem entrada de serviço; no térreo existe um WC de uso coletivo. Também não há garagens, embora existam recuos laterais.

mais surpreendente, porém, no edifício Dona Veridiana, é o absoluto descompasso entre seu exterior e a distribuição planimétrica interna. Com efeito, no exterior, a fachada principal é absolutamente simétrica a partir de um eixo vertical central que encima a entrada do edifício, sugerindo a existência de apartamentos idênticos, apenas rebatidos, de cada um dos lados. Aparentemente, portanto, mantinham-se as lições de composição simétrica herdadas do sistema Beaux Arts pelo Art déco. Contudo, como vemos nas plantas, as janelas centrais - que ladeiam o eixo de simetria da fachada - pertencem não só ao mesmo apartamento como à mesma sala ${ }^{38}$. Trata-se, portanto, de uma solução de caráter formalista - corroborada, aliás, por outros recursos de efeito, como os balanços dos terraços laterais, as marquises superiores e as janelas de canto nos dormitórios das extremidades. 


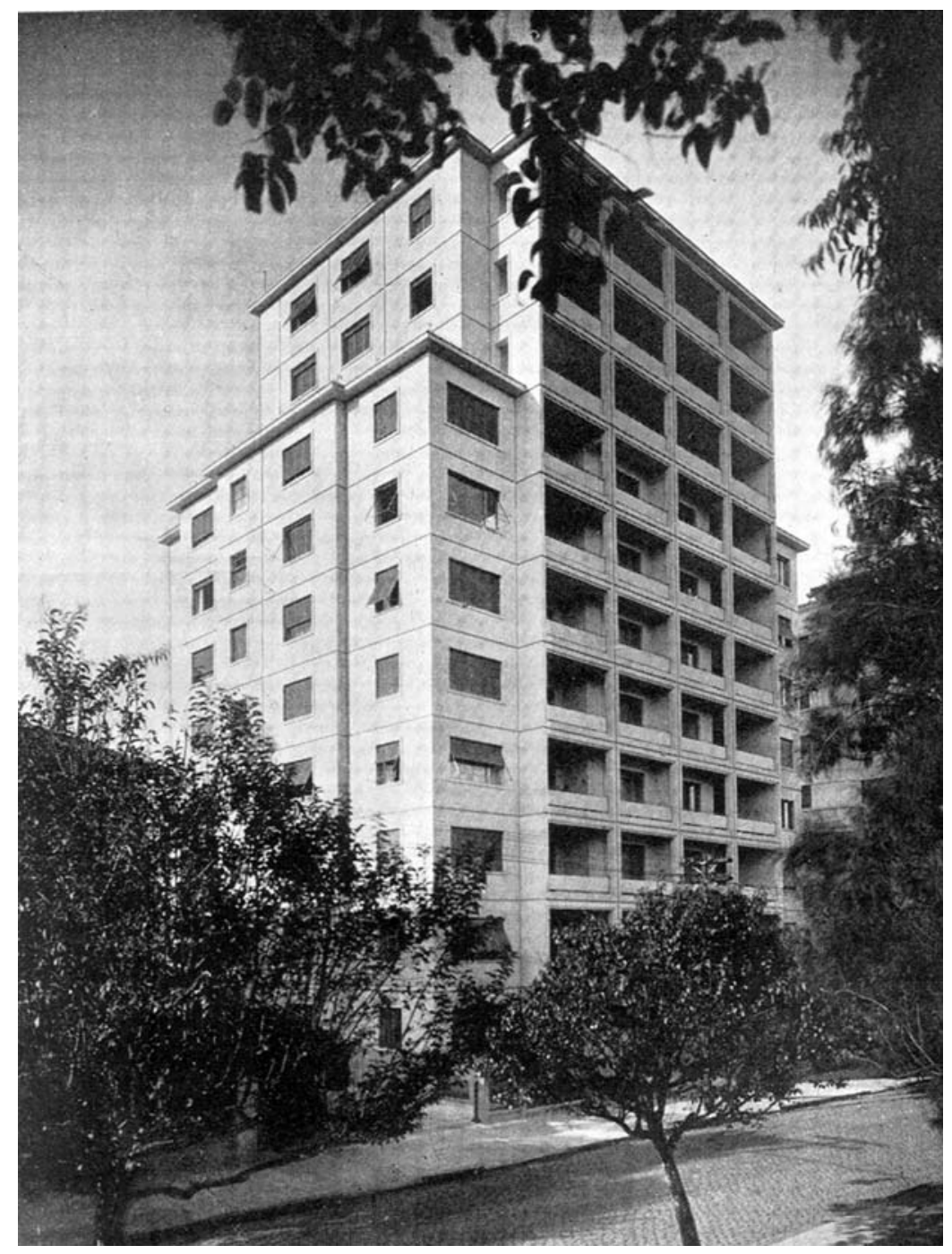

Figura 24 - Edifício Santa Amália, rua Piauí, projetado e construído pelo Escritório Técnico Francisco Matarazzo Netto (ACROPOLE, ago. 1943, p. 93).

Já o Edifício Santa Amália (rua Piauí 760), projetado e construído pelo E. T. Francisco Matarazzo Netto, constitui exemplo dos apartamentos "de grande luxo" construídos no período ${ }^{39}$ (Figura 24). Assim como o Dona Veridiana, não apresenta lojas no térreo, configurando-se como edifício exclusivamente residencial; como aquele, também não foge à regra no que diz respeito à existência de tipologias variadas - o que aliás é denotado pela sua volumetria movimentada (Figura 25). Até o 7 . andar, cada pavimento tem 2 apartamentos, um de 2 e outro de 3 quartos, além de sala de estar, sala de jantar, banheiro, copa, cozinha, área de serviço e dependências de empregada - tudo interligado por circulações generosas (Figura 26). Do 8. ao 10. pavimentos, há apenas um apartamento por andar, com 4 quartos (um dos quais isolado dos demais, 


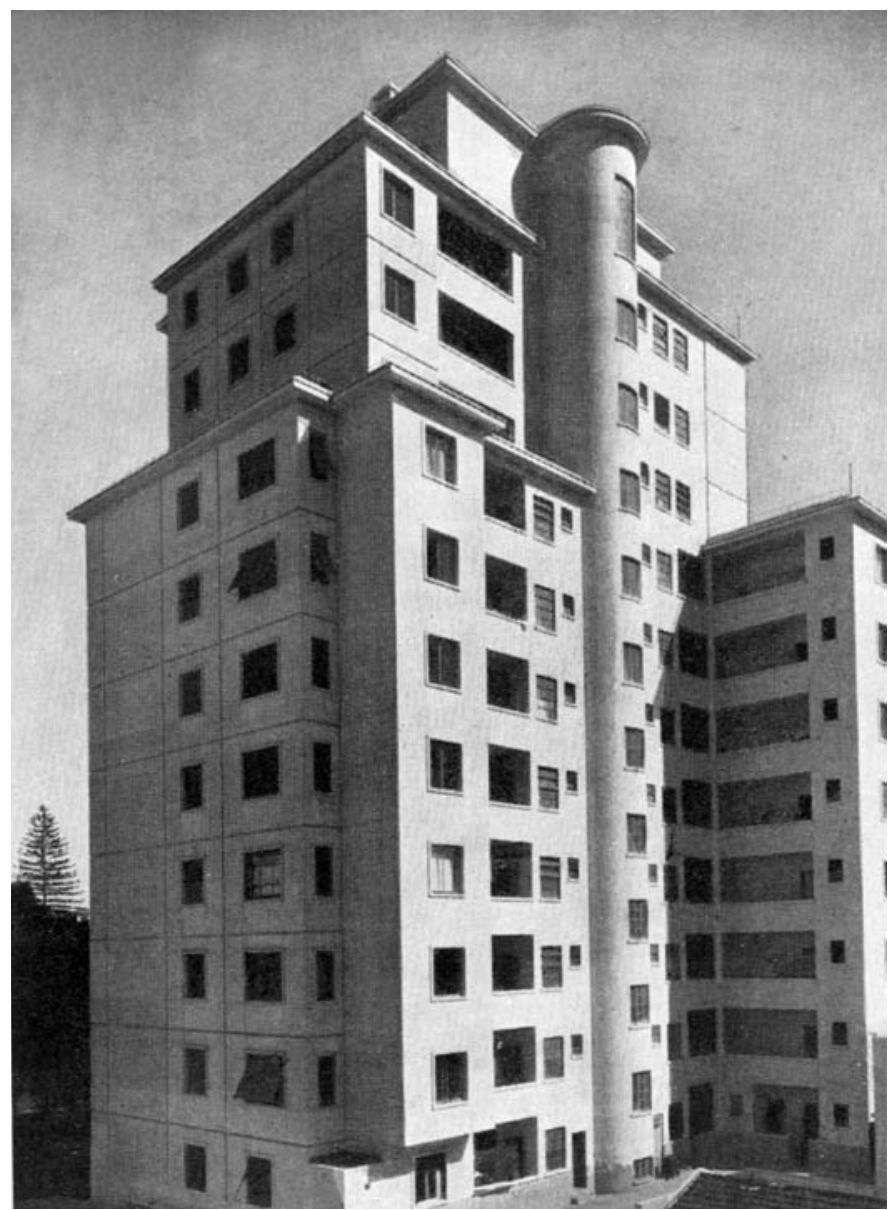

Figura 25 - Vista posterior do Edifício Santa Amália e sua volumetria movimentada (ACRÓPOLE, ago. 1943, p. 95). talvez para permitir sua transformação em escritório e dois banheiros completos - agenciamento absolutamente excepcional no período -, além das demais dependências encontradas nas outras unidades. As grandes dimensões dos apartamentos corroboram seu caráter de edifício de luxo, assim como a especialização do programa, que passa a incluir copa, área de serviço com 2 tanques e despensa. Persiste, porém, a inexistência de lavabos, imprescindíveis nas residências unifamiliares de mesmo padrão no período ${ }^{40}$ (Figura 27). Cabe destacar a preocupação - explícita no artigo citado - com a "perfeita separação entre os inquilinos e o movimento da parte de serviço".

Formalmente, o Edifício Santa Amália é bastante sóbrio e despojado, valendo-se principalmente de recursos como o jogo de volumes de alturas diferentes e do contraste entre cheios e vazios. Nesse sentido, aproxima-se da arquitetura monumental classicizante de matriz italiana que se disseminou em São Paulo na década de 1940, após a inauguração do Edifício Matarazzo, atual sede da Prefeitura de São Paulo ${ }^{41}$.
40. O já mencionado Edifício Wancolle, projeto de Rino Levi, apresenta lavabo no apartamento de cobertura destinado à residência do proprietário, Sr. Wancolle. Entretanto, não há lavabos nos demais apartamentos do edifício - que podem ser considerados apartamentos de luxo, existindo apenas uma unidade por andar, com grandes dimensões. Ver Renato Anelli (1974).

41.A proximidade entre esta arquitetura e o Art-Déco é discutida no item $3.3 \mathrm{de} \mathrm{mi-}$ nha tese de doutoramento, já referida. 
Figura 26 - Planta do pavimento-tipo do Edifício Santa Amália (ACRÓPOLE, ago. 1943, p. 94).

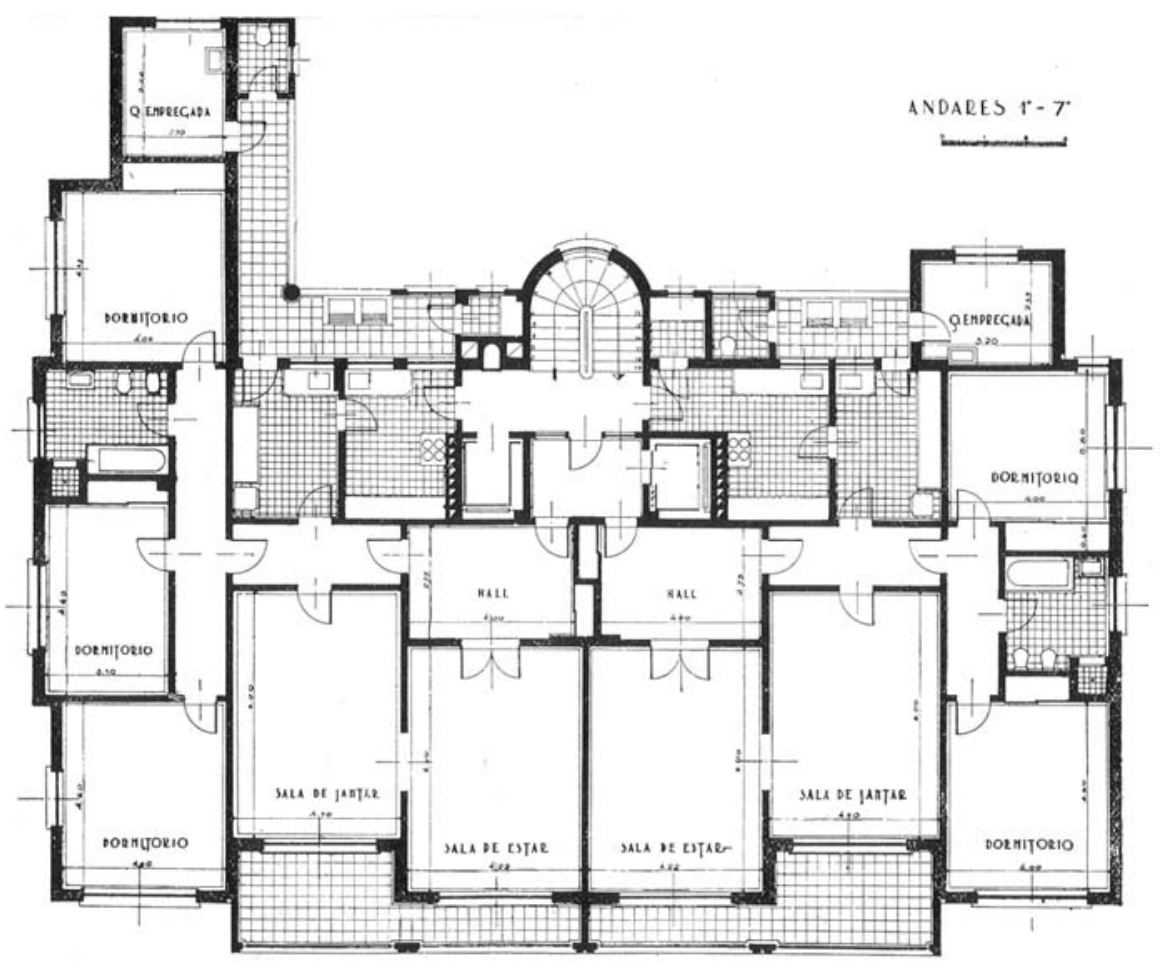

Figura 27 - Planta dos pavimentos 8 , 9 e 10 do Edifício Santa Amália (ACRÓPOLE, ago. 1943, p. 94).

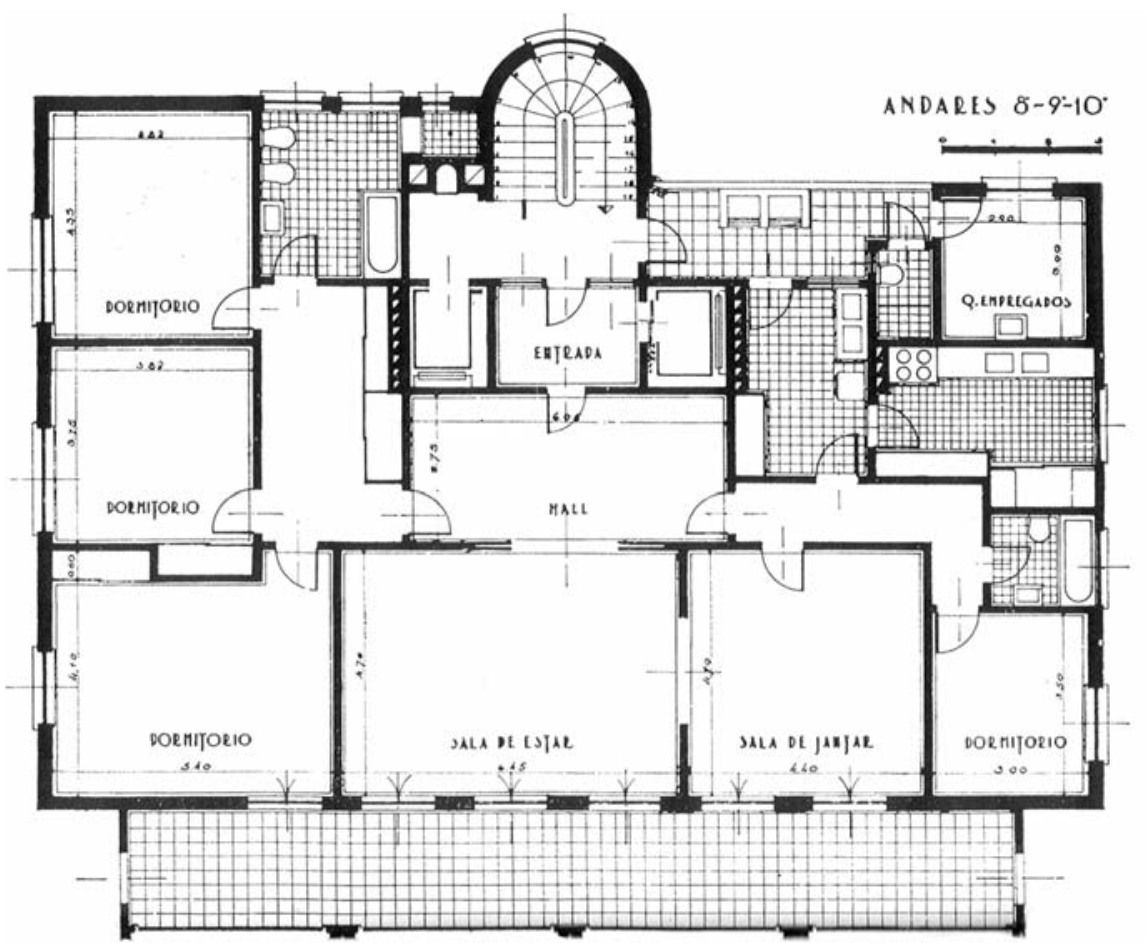




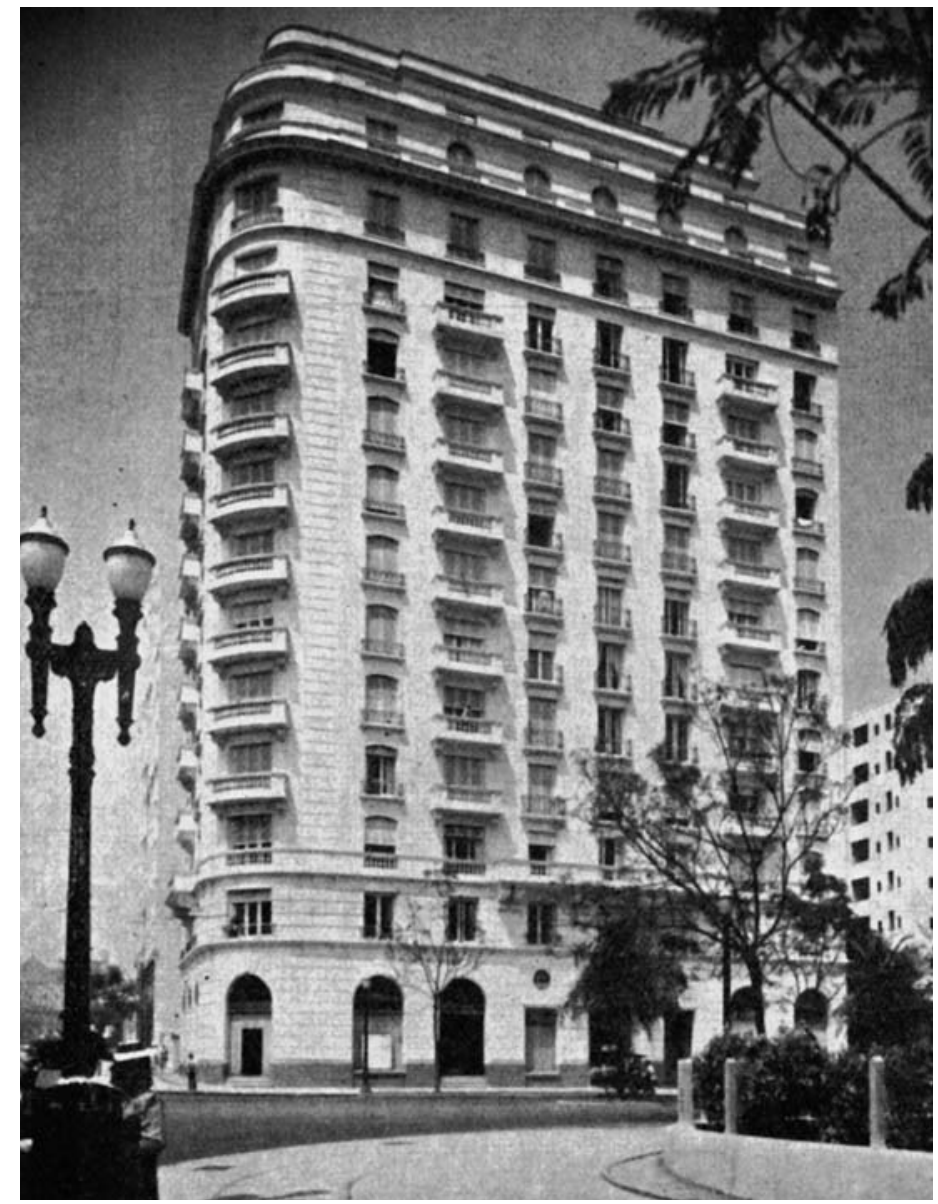

Figura 28 - Edifício São Luiz, rua São Luís com avenida lpiranga, projetado por Jacques Pilon (ACRÓPOLE, jan.fev. 1945, p. 290).

A esse respeito, é interessante comparar o Santa Amália com outro edifício de luxo construído em São Paulo nos mesmos anos: o Edifício São Luiz (rua São Luís esquina com avenida lpiranga) ${ }^{42}$, projetado por Jacques Pilon (Figura $281^{43}$. Neste caso, provavelmente por se tratar de um edifício destinado a uma clientela abastada, o arquiteto - justamente ele, por vezes considerado um dos pioneiros da arquitetura moderna em São Paulo - não hesitou em adotar um estilo classicizante afrancesado na composição, em flagrante oposição à arquitetura comercial que ele vinha praticando no centro de São Paulo ${ }^{44}$. Pilon demonstra, dessa forma, uma espécie de conveniente adesão aos princípios do ecletismo tipológico ${ }^{45}$, ao diferenciar claramente a arquitetura dos edifícios de escritórios que construía então no centro de São Paulo de suas obras residenciais, para as quais preconizava uma arquitetura de 'estilo'. Parece ter inaugurado, portanto, a onda de edifícios residenciais neoclássicos que até hoje assola a cidade, atendendo a um gosto mais conservador e ansioso pelo requinte capaz de afastar definitivamente o fantasma dos "cortiços de luxo"
42. Ver Acrópole (jan.-fev. 1945, p. 81-82)

43. Ao que indica o estado atual da pesquisa, os edifícios de luxo eram muito menos numerosos do que os demais; entre os 35 edifícios residenciais pesquisados, apenas o Santa Amália e o São Luiz podem ser incluídos nesta categoria, pelas dimensões dos apartamentos e pela especialização do programa.

44 Sobre a obra de Jacques Pilon, ver I. H. D. Castello BRANCO, 1988. Neste trabalho, consta que o projeto do Edifício São Luiz - considerado "o primeiro prédio de apartamentos de alto luxo da cidade"- é de 1940, e que a conclusão da obra deu-se em 1944 (p. 263). Quanto às características formais do São Luiz, deve-se notar que, em data tão tardia quanto 1950, Pilon recorreu mais uma vez ao classicismo francês na residência Oscar Cintra Gordinho à Av. Higienópolis, que é uma cópia do $P e$ tit Trianon de Versalhes (LEFÈVRE, s.d.spn). Por outro lado, as soluções de planta dos apartamentos do edifício em nada diferem do quadro delineado aqui.

45. A respeito, ver Luciano Patteta (1987). 
46. Na década de 1930, Rino Levi projetou vários edifícios, a maioria de apartamentos residenciais, além do Columbus e do Higienópolis: o Edifício Nicolau Schiesser (1934); o já mencionado Edifício Wancole (1935); os Edifícios Sarti e Henrique Jovino, também de 1935; e o Edifício Guarany (1936). A respeito, ver Lúcio Gomes Machado (1992).
Ainda dentro da abordagem da arquitetura residencial verticalizada em São Paulo, entre 1930 e 1940, é oportuno destacar algumas das primeiras obras da carreira de Rino Levi, que não tem merecido muita atenção - certamente porque, nelas, a contribuição definitiva do arquiteto ainda não se apresenta plenamente amadurecida. No entanto, a atuação de Levi exerceu influência significativa sobre seus colegas de profissão já desde os anos 1930, como procuraremos demonstrar a partir da análise de dois de seus projetos de edifícios em altura: o Edifício Columbus e o Prédio Higienópolis ${ }^{46}$. Neles, soluções que se tornariam a norma em prédios residenciais nas décadas seguintes racionalização dos espaços e padronização de plantas, concentração de áreas molhadas, previsão de equipamentos coletivos, tratamento de fachadas encontram-se já indicadas, ainda que não plenamente desenvolvidas.

O Edifício Columbus, construído em 1934, constitui exemplo precoce de edifício residencial de porte em São Paulo (Figuras 29). A análise deste prédio indica que, se sob muitos pontos de vista ele se enquadra claramente no panorama delineado acima - o que vem corroborar sua influência sobre a arquitetura verticalizada em São Paulo, dada sua precedência cronológica -, é certo também que nele pode identificar-se uma busca evidente pela qualidade e racionalidade do projeto, de uma perspectiva muito própria de seu autor.

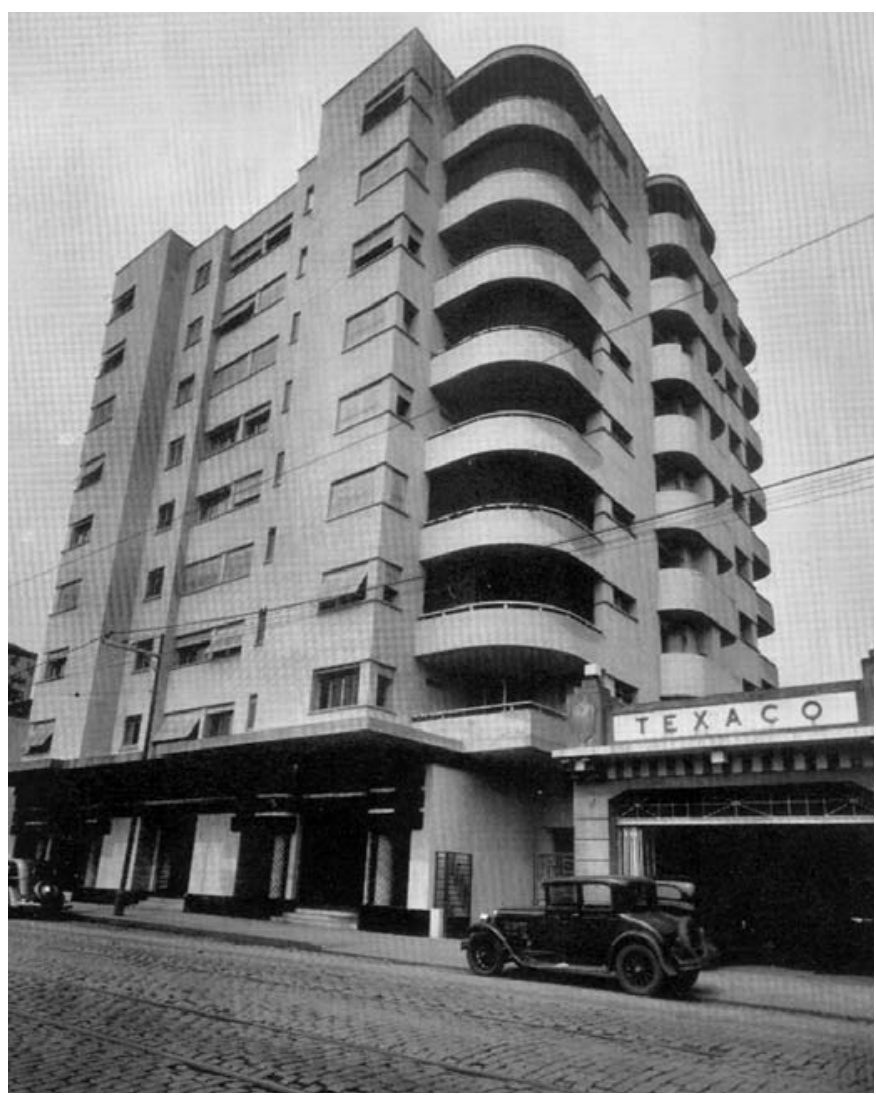

Figura 29 - Vista geral do Edifício Columbus, rua Brigadeiro Luís Antônio, projetado por Rino Levi. (RINO LEVI, 1974, p. 311 . 
Trata-se de edifício de 10 andares, cuja planta revela a existência de 2 tipologias de apartamentos, de distribuição planimétrica bastante semelhante, variando apenas as dimensões da sala de visitas e o número de dormitórios - um tipo de 2, outro de 3 quartos (Figura 30). Na tipologia menor, com 2 quartos, foi eliminado também o quarto de empregada, mantendo-se o WC de serviço. Os 4 apartamentos existentes em cada andar são iguais, 2 a 2, apenas rebatidos, configurando uma planta desenvolvida a partir do cruzamento de dois eixos principais - como preconizavam os critérios tradicionais de composição. Assim, ainda que a planta seja bastante recortada, traduzindose numa volumetria movimentada - características usuais da arquitetura residencial do período -, o resultado é de fácil leitura e o exterior do edifício é absolutamente condizente com o interior, o que nem sempre ocorria nos edifícios residenciais de então, como vimos.

Construtivamente, não há inovações a registrar em relação a edifícios seus contemporâneos, excetuando-se o uso de esquadrias metálicas em todas as janelas - de correr ${ }^{47}$ (Figura 31 ) e basculantes -, associadas, nos ambientes de permanência prolongada, a venezianas de enrolar.

Formalmente, entretanto, cabem algumas considerações. Como já observado, o edifício apresenta volumetria movimentada, cujo jogo de balanços e contraste entre cheios e vazios substitui, por assim dizer, a necessidade de ornamentação superficial. Embora identifique-se um maior cuidado no piso térreo, na fachada principal - que recebe revestimento em pedra e detalhamento Art déco (Figura 32) -, daí para cima todas as fachadas recebem tratamento equivalente, podendo-se mesmo dizer que as fachadas laterais, onde se concentram as áreas menos nobres dos apartamentos (banheiros, cozinha e área de serviço) apresentam maior virtuosismo de desenho. É digna de nota a simulação
47. Em palestra proferida no IAB-SP, $\mathrm{o}$ arquiteto Jorge Wilhelm atribuiu a Rino Levi o desenho do fecho das esquadrias metálicas de correr desde então usualmente utilizadas.

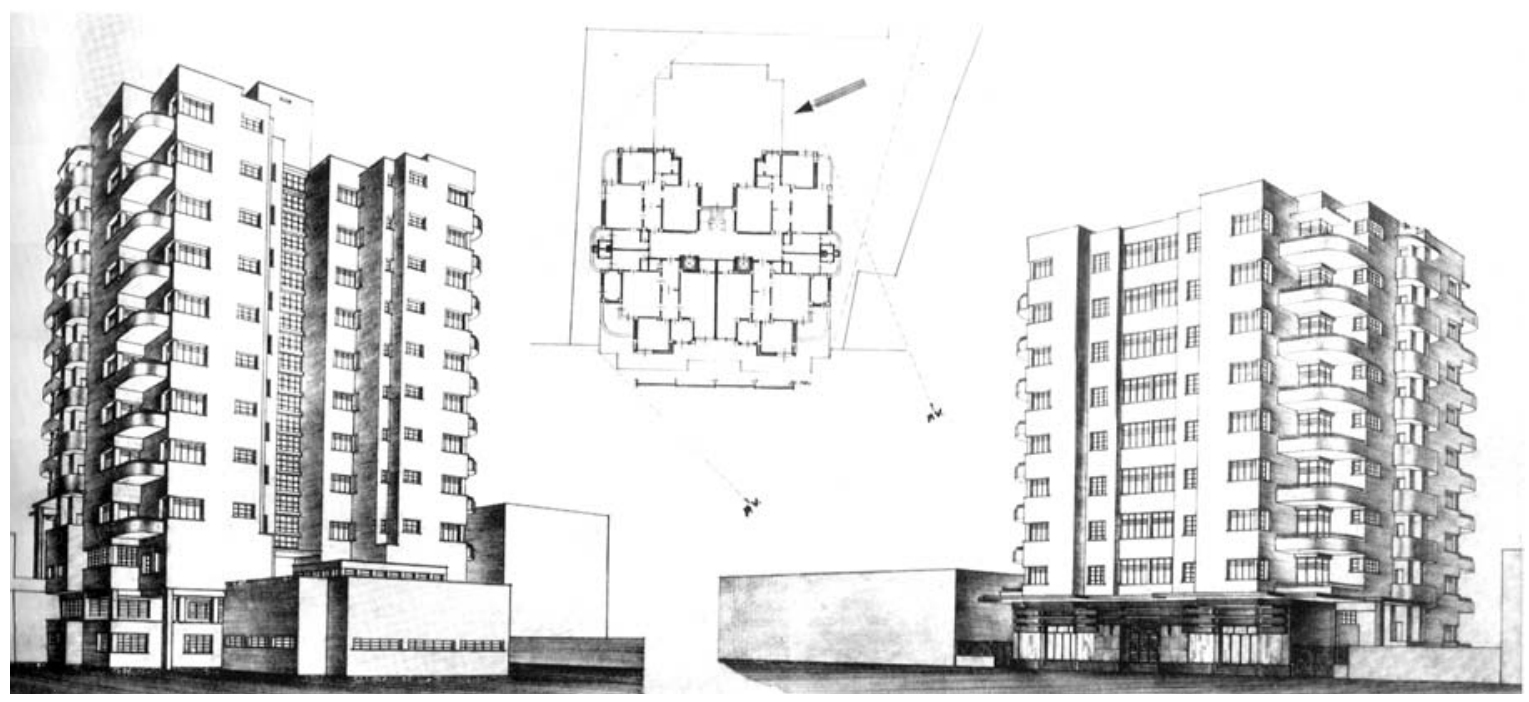

Figura 30 - Planta (ao centro) e perspectivas do Edifício Columbus: à direita, fachada principal; à esquerda, fachada posterior (RINO LEVI, 1974, p. 31 ). 

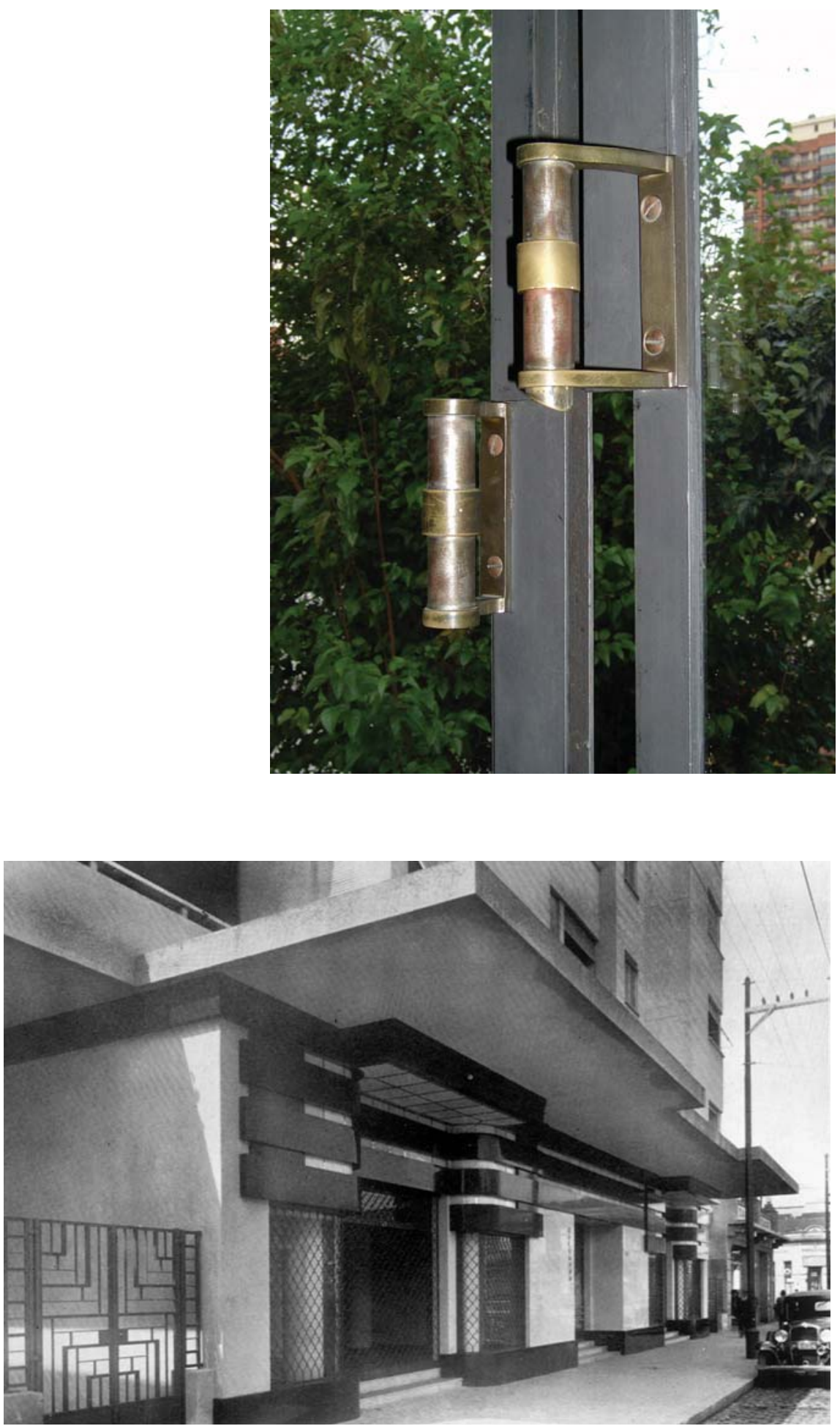

Figura 31 - Detalhe de fecho de janela de correr projetado por Rino Levi, muitíssimo usual nas décadas de 1930 e 1940, inclusive em obras de outros arquitetos. Residência da autora. Fotografia de Maria Lucia Bressan Pinheiro, 2007.

Figura 32 - Tratamento do piso térreo do Edifício Columbus, com revestimento em pedra e detalhamento Art déco (RINO LEVI, 1974, p. 32). 
de janelas de canto - solução introduzida por Warchavchik na Casa da Rua Santa Cruz, e muito adotada desde então.

É necessário comparar este primeiro projeto vertical de Rino Levi com outro, construído poucos anos mais tarde, onde a linguagem utilizada é a mesma, mas identificam-se mudanças importantes na concepção dos apartamentos, além de um maior apuro construtivo. Trata-se do Prédio Higienópolis (1935-1936) ${ }^{48}$, na rua Conselheiro Brotero (Figura 33). Aqui, podem ser apontadas algumas inovações, como a inexistência de tipologias diferenciadas nos andares-tipo e a valorização do último andar.

De fato, no Prédio Higienópolis, todos os andares-tipo tem o mesmo número de unidades, todos de mesma área e planta praticamente igual, dispostos simetricamente a partir da intersecção de dois eixos (Figura 34). A tipologia

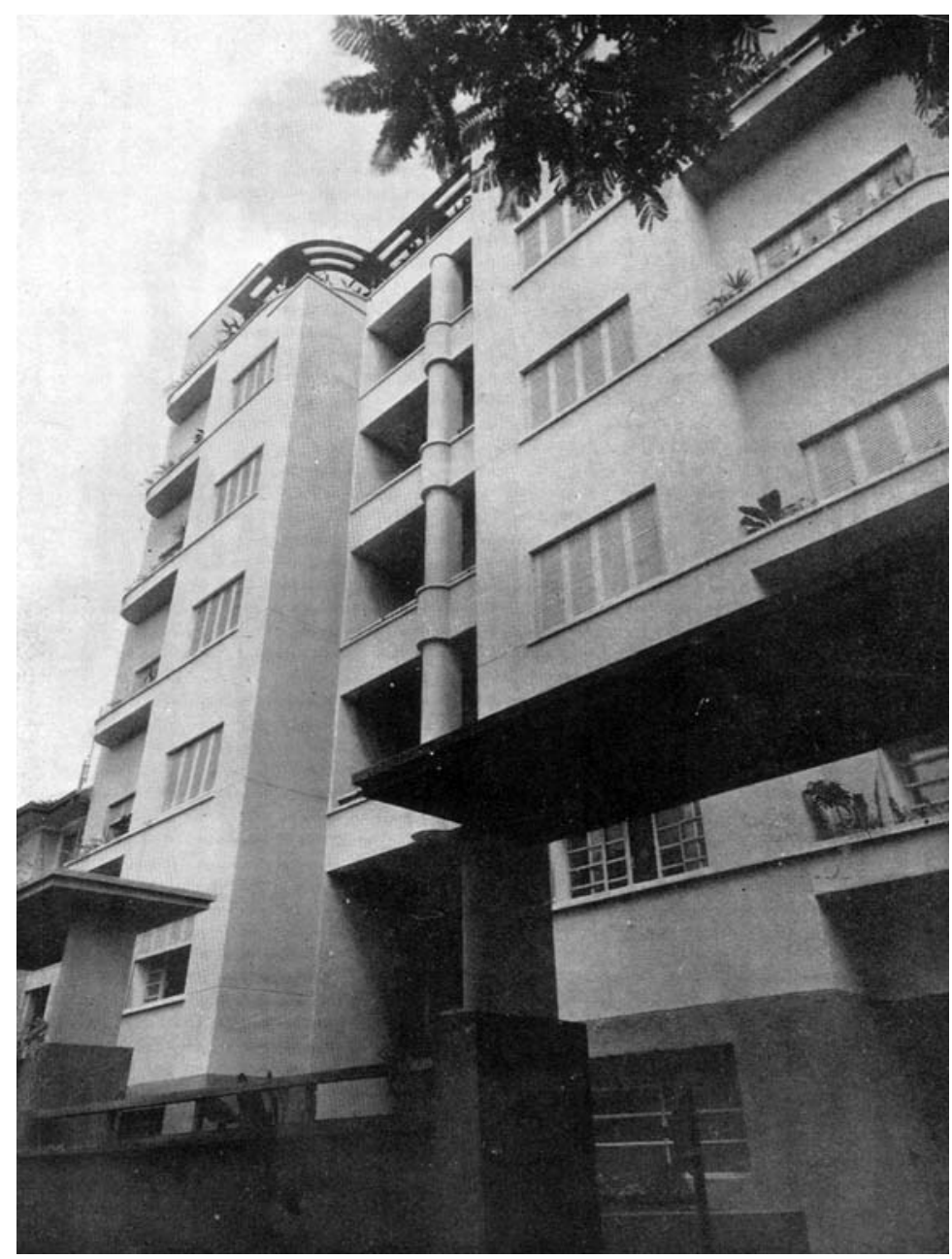

Figura 33 - Fachada principal do Prédio Higienópolis, rua Conselheiro Brotero, projetado por Rino Levi (ACRÓPOLE, jul. 1940, p. 107). 


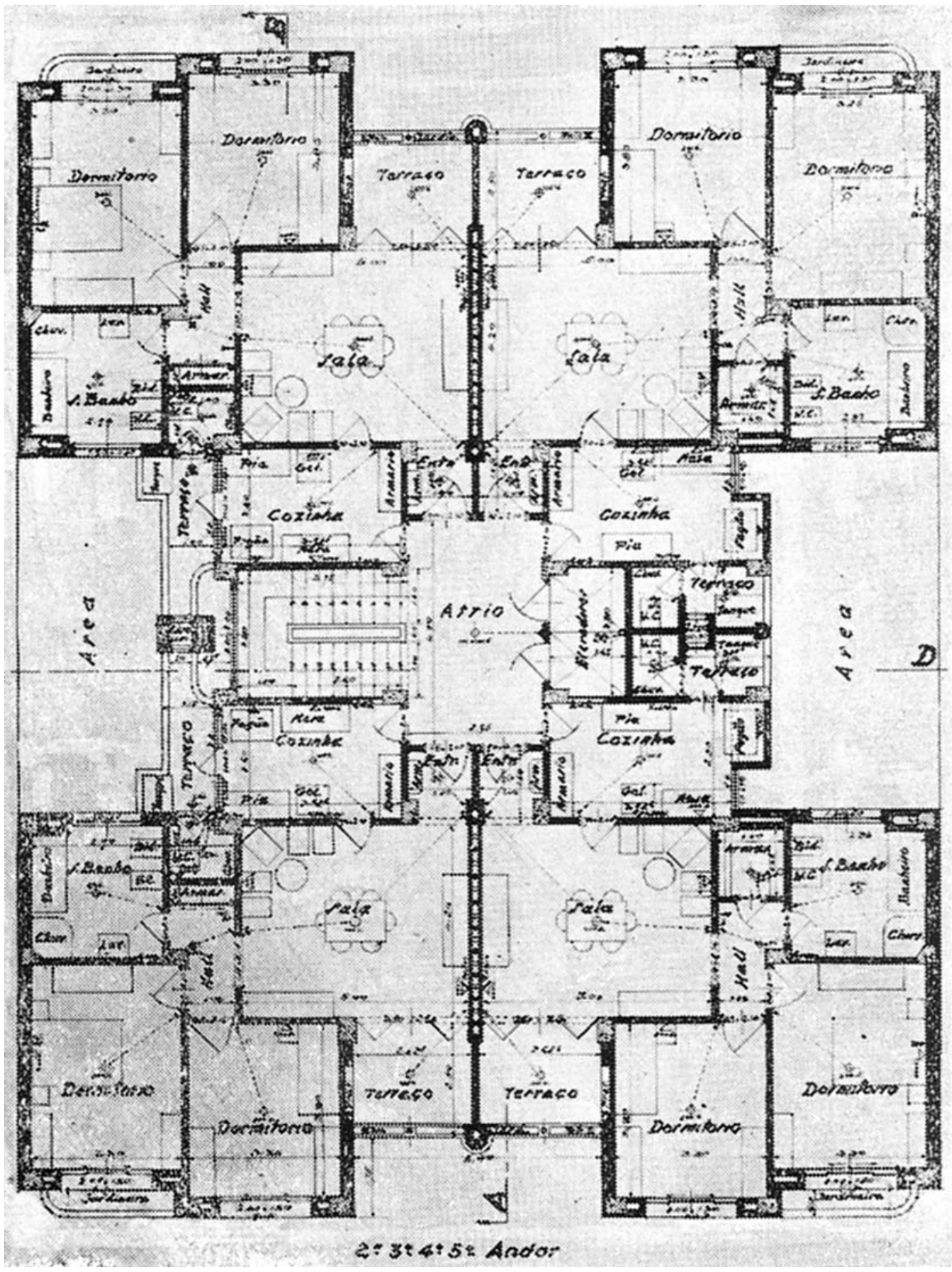

Figura 34 - Planta do andar-tipo do Prédio Higienópolis (ACRÓPOLE, jul. 1940, p. 110 ). 


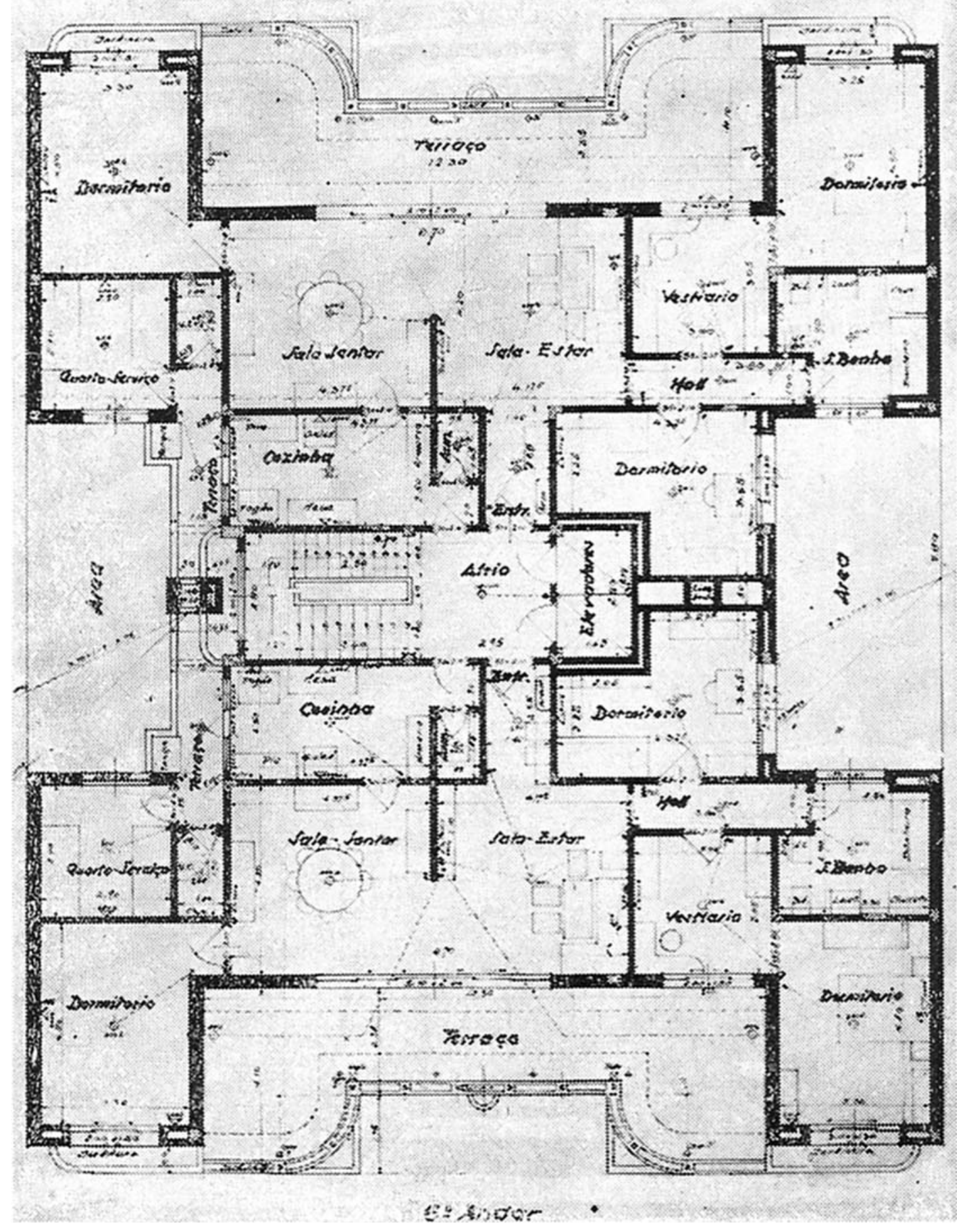

Figura 35 - Planta do último andar do Prédio Higienópolis (ACRÓPOLE, jul. 1940, p. 109). 
49.Cf.Acrópole (n.27,p.107, 1940).

50. Idem, p. 111

51. Ver Fernando Atique (2004, p. 238). básica, rebatida 2 a 2 e repetida em todos os andares do edifício, compõe-se de sala, dois quartos, cozinha, banheiro, área de serviço e WC de empregada. Segundo o arquiteto, "a planta caracteriza-se pela forma intensiva de agrupamento e é estandardizada ao máximo" 49 . Apenas no térreo e na cobertura desenvolvemse soluções diferenciadas: no térreo, variam as dimensões dos apartamentos, devido à interferência do hall de entrada, elevadores e circulações; na cobertura, para aproveitamento da vista privilegiada, localizam-se apenas 2 apartamentos de dimensões maiores e amplos terraços pergolados (Figura 35), a prenunciar a postura contemporânea de valorização dos andares altos. Essa solução pode ter sido inspirada pela localização do edifício, com vista para o então quase vazio vale do Pacaembu (Figura 36).

aproveitamento do forte declive do terreno para construção de um bloco de garagens, junto à divisa posterior do lote, é outra solução inovadora. Entre este bloco e o edifício principal, foi prevista uma área ajardinada e a colocação de alguns brinquedos para crianças (Figura 37). As dependências de empregada foram agrupadas sobre a garagem, excetuando-se as dos apartamentos de cobertura, que se localizam junto às respectivas áreas de serviço.

Importante cuidado tomado pelo arquiteto quanto ao conforto acústico é a construção, indicada nas plantas, de paredes divisórias duplas "com câmara de ar intermediária" 50 entre os apartamentos. Existe também a preocupação expressa de agrupar as instalações de água e esgoto, para a racionalização da construção. O detalhamento da caixilharia é equivalente ao do Edifício Columbus.

Formalmente, as fachadas fronteira e posterior do edifício - que foi construído sobre as divisas laterais do terreno, prevendo-se a construção posterior de prédios vizinhos -, resultam, ambas. da distribuição planimétrica interna e recebem tratamento equivalente, baseado em volumetria movimentada, com balcões em balanço, semelhantes aos existentes no Edifício Columbus (Figura 38).

Em relação ao panorama da arquitetura verticalizada em São Paulo nas décadas de 1930 e 1940, pode-se perceber que os edifícios de Rino Levi aqui analisados inserem-se numa etapa inicial das pesquisas sistematicamente empreendidas pelo arquiteto, visando à maior funcionalidade das construções, em termos de implantação no lote e distribuição interna dos ambientes, bem como avanços na qualidade técnica da construção e no que toca ao conforto ambiental. É oportuno observar que as soluções utilizadas por ele nos edifícios aqui analisados passaram a predominar sobre os esquemas primordialmente voltados à maximização dos lucros, usualmente utilizados até então. Chama a atenção, por outro lado, a não-adesão imediata de Levi ao repertório formal moderno- que ele conhecia bem, posto que residiu no Edifício Esther entre 1941 e 1944, além de manter escritório ali ${ }^{51}$-, o que parece indicar seu engajamento pessoal na melhoria efetiva dos parâmetros arquitetônicos vigentes, sem a preocupação de recorrer a soluções apenas superficialmente inovadoras.

A análise ora desenvolvida buscou apontar a diversidade de soluções encontradas nos primeiros exemplares da arquitetura residencial verticalizada em São Paulo - rico manancial de temas de pesquisa sobre os modos de construir 

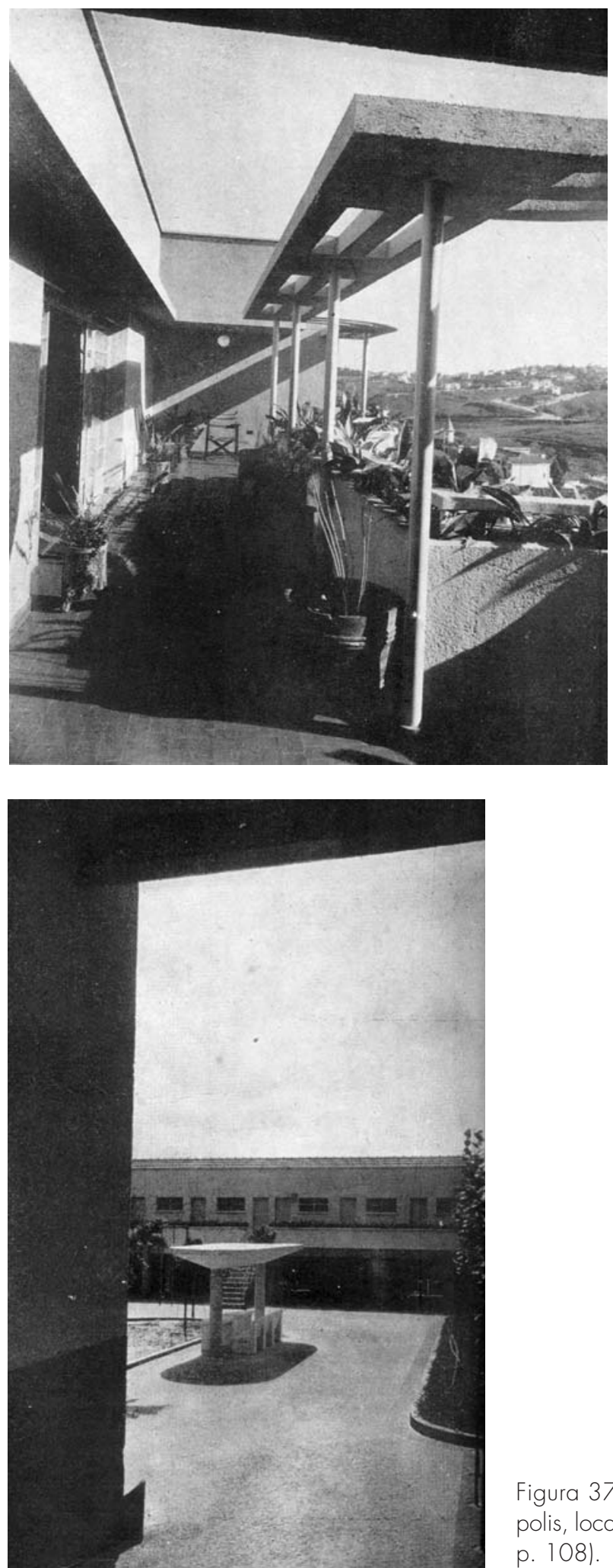

Figura 37 - Vista do bloco de garagens do Prédio Higienópolis, localizado nos fundos do terreno (ACRÓPOLE, jul. 1940, p. 108).
Figura 36 - Terraço do último andar do Prédio Higienópolis, com vista para o vale do Pacaembu (ACRÓPOLE, jul. 1940, p. 109). 


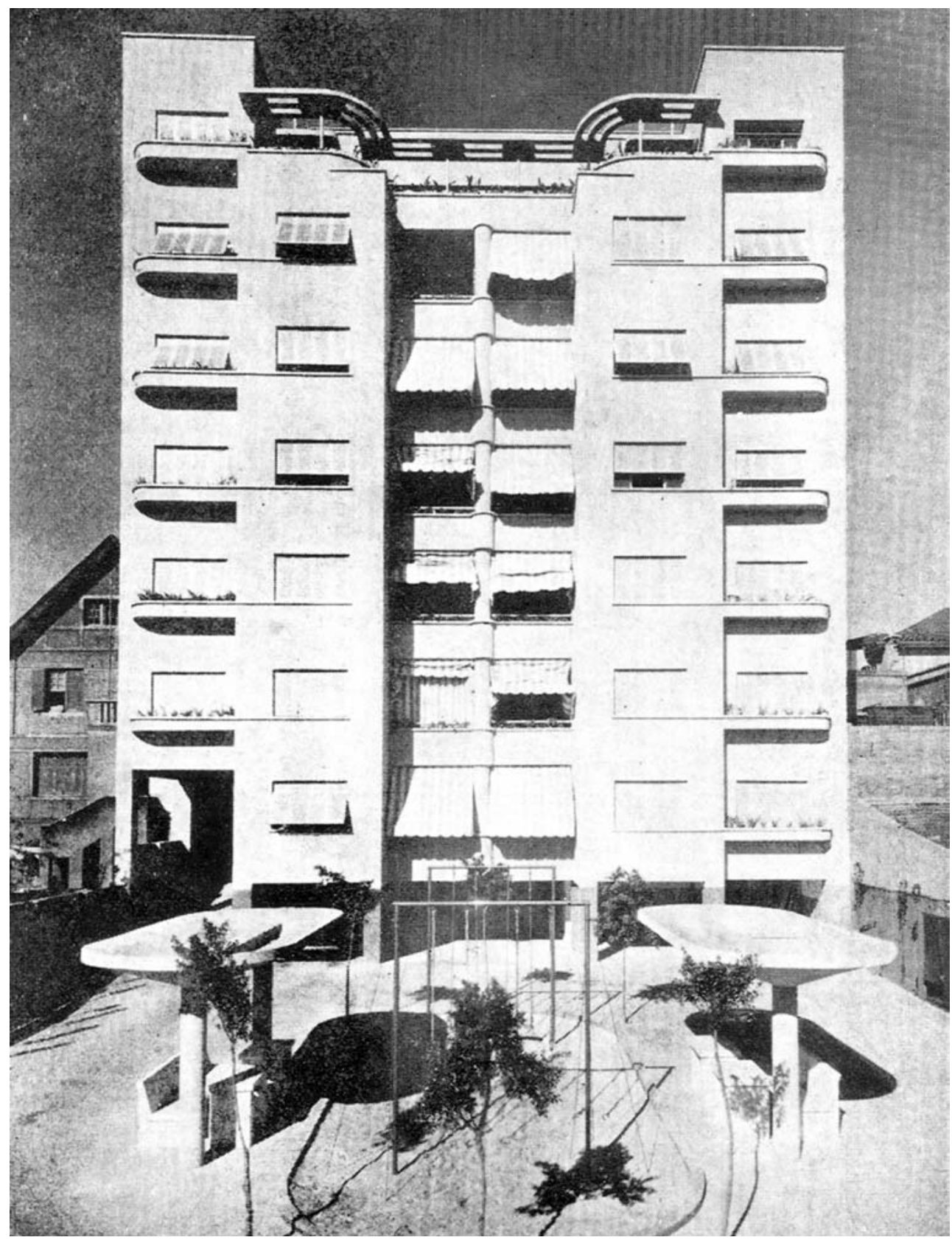

Figura 38 - Fachada posterior do Prédio Higienópolis (ACRÓPOLE, jul. 1940, p. 108). 
e de viver em São Paulo, no período em questão. Trata-se de conjunto significativo, porém envolto em flagrante indiferença, por não enquadrar-se facilmente nos valores arquitetônicos consagrados; com efeito, não se trata de edifícios excepcionais, nem muito antigos, nem tampouco inequivocamente modernos; são, isto sim, representativos deste momento menosprezado da história de nossa arquitetura situado entre as décadas de 1930 e 1940.

Os numerosos exemplares remanescentes, muitos deles ainda razoavelmente íntegros, constituem importante patrimônio de São Paulo, pois evidenciam caminhos diversos e não necessariamente vitoriosos na produção imobiliária da cidade voltada à habitação. A pouca atenção a eles dispensada pela historiografia é risco certo à tentativa de compreender este período das moradias verticais da cidade, pois foram pouco documentados e poucos deles lograram obter proteção pelos instrumentos oficiais de preservação. Seu desaparecimento ou descaracterização acarretará, portanto, a transformação radical da imagem da área central da cidade - a obliteração de mais uma camada daquele pergaminho de que, com tanta pertinência, falou Benedito Lima de Toledo:

A cidade de São Paulo é um palimpsesto - um imenso pergaminho cuja escrita é raspada de tempos em tempos, para receber outra nova, de qualidade literária inferior, no geral ${ }^{52}$.

\section{REFERÊNCIAS}

ANELLI, Renato. Rino Levi: arquitetura e cidade. São Paulo: Romano Guerra, 2001.

ATIQUE, Fernando. Memória moderna: a trajetória do Edifício Esther. São Carlos: RiMa/Fapesp, 2004.

BAYER, Patricia. Art deco architecture. New York:Abrahams, 1992.

BRANCO, Ilda Helena D. Castello. Arquitetura no centro da cidade: edifícios de uso coletivo. São Paulo. 1930-1950. 1988. Dissertação (Mestrado) - Faculdade de Arquitetura e Urbanismo, Universidade de São Paulo, São Paulo, 1988.

CAMPOS, Vitor José Baptista Campos. O art-déco na arquitetura paulistana: uma outra face do moderno. 1996. Dissertação (Mestrado) - Faculdade de Arquitetura e Urbanismo, Universidade de São Paulo, São Paulo, 1996.

CONDE, Luiz Paulo et al. Proto-modernismo em Copacabana: uma arquitetura que não está nos livros. Arquitetura Revista, Rio de Janeiro, n. 3, p. 40-49, 1985 [FAU-UFRJ].

CORONA, Eduardo; LEMOS, Carlos; XAVIER,Alberto. Arquitetura moderna paulistana. São Paulo: Pini, 1983.

EDIFÍCIO Buenos Aires. Acrópole, São Paulo, n. 53, p. 191-192, set. 1942.
52. Cf. Benedito Lima de Toledo (1981, p. 67) 
EDIFÍCIO Gonçalves Biar. Acrópole, São Paulo, n. 12, p. 51-56, abr. 1939.

EDIFÍCIO João Alfredo. Acrópole, São Paulo, n. 53, p. 173-174, set. 1942.

EDIFÍCIO Regência.Acrópole, São Paulo, n. 26, p. 79-87, jun. 1940.

EDIFÍCIO Santa Amália. Acrópole, São Paulo, n. 64, p. 93-99, ago. 1943.

EDIFÍCIO São Luís. Acrópole, São Paulo, n. 81-82, p. 290-291, jan.-fev. 1945.

FERRAZ, Geraldo. Warchavchik e a introdução da nova arquitetura no Brasil: 1925 a 1940. São Paulo: Masp, 1965.

LEFÈVRE, José Eduardo de Assis. Critérios para Restauro: Residência da Avenida Higienópolis 870. São Paulo: [s. n.], [19-].

Entre o discurso e a realidade: a quem interessa o centro de São Paulo? A rua São Luiz e sua evolução. 1999. Tese (Doutorado) - Faculdade de Arquitetura e Urbanismo, Universidade de São Paulo, São Paulo, 1999.

LEMOS, Carlos. Cozinhas, etc.: um estudo sobre as zonas de serviço da casa paulista. São Paulo: Perspectiva, 1976.

.Edifícios residenciais em São Paulo: da sobriedade à personalização. Projeto, São Paulo, n. 133, p. 57-58, jul. 1990.

LINDENBERG, ALVES E ASSUMPÇÃO Engenheiros Civis e Constructores, 1920-1940. São Paulo: [s. n.], [19-].

MACHADO, Lúcio Gomes. Rino Levi. 1992. Tese (Doutorado) - Faculdade de Arquitetura e Urbanismo, Universidade de São Paulo, São Paulo, 1992.

PATETTA, Lucian. Considerações sobre o Ecletismo na Europa. In: FABRIS, Annateresa (Org.). Ecletismo na arquitetura brasileira. São Paulo: Nobel, 1987. p. 8-27.

PINHEIRO, Maria Lucia Bressan. Modernizada ou moderna? A arquitetura em São Paulo, 193845. Tese (Doutorado) - Faculdade de Arquitetura e Urbanismo, Universidade de São Paulo, São Paulo, 1997.

.Modernizada ou moderna? A arquitetura em São Paulo nas décadas de 1930 e 1940. Revista Pós. São Paulo, n. 9, p. 108-117, jun. 2001 [FAU-USP].

Moderno ou Moderne? Questões sobre a arquitetura francesa no entre-guerras. In: SEMINÁRIO INTERNACIONAL ART-DÉCO NA AMÉRICA LATINA, 1. 1997, Rio de Janeiro. Anais... Rio de Janeiro: Prefeitura da Cidade do Rio de Janeiro; PUC-RJ, 1997. p. 205-210.

Neocolonial, modernismo e preservação do patrimônio no debate cultural dos anos 1920 no Brasil. 2005. Tese (Livre-Docência) - Faculdade de Arquitetura e Urbanismo, Universidade de São Paulo, São Paulo, 2005. 
PRADO, Yan de Almeida (João Fernando de Almeida Prado). Apontamentos para uma história da arquitetura em São Paulo, escrito a pedido do GFAU em 1957. Depoimentos, n. 1, São Paulo, p. 11-26, abr. 1960 [Publicação periódica para o debate de Arquitetura; Grêmio da Faculdade de Arquitetura e Urbanismo].

PRÉDIO Dona Veridiana. Acrópole, São Paulo, n. 43, p. 279-80, 1941.

PRÉDIO Higienópolis. Acrópole, São Paulo, n. 27, p.107-112, 1940.

PRÉDIO Lívia Maria. Acrópole, São Paulo, n. 1, p. 52-53, 1938.

PRÉDIO Maria Tereza.Acrópole, São Paulo, n. 67, p. 198-200, nov. 1943.

PRÉDIO Zena.Acrópole, São Paulo, n. 23, p. 33-38, 1940.

RINO Levi. Intr. Roberto Burle Marx; Nestor Goulart Reis Filho. Milano: Communità, 1974.

SOMEKH, Nadia. A cidade vertical e o urbanismo modernizador: São Paulo 1920-1939. Tese (Doutorado) - Faculdade de Arquitetura e Urbanismo, Universidade de São Paulo, São Paulo, 1994.

TOLEDO, Benedito Lima de. São Paulo: três cidades em um século. São Paulo: Duas Cidades, 1983.

VAUTHIER, Louis Léger. Casas de Residência no Brasil. In: FAU-USP; MEC-IPHAN. Textos escolbidos da Revista do Instituto do Patrimônio Histórico e Artístico Nacional:Arquitetura Civil I. São Paulo: FAU-USP, 1975.

VAZ, Lílian Fessler. Uma história da habitação coletiva na cidade do Rio de Janeiro: estudo da modernidade através da moradia. Tese (Doutorado) - Faculdade de Arquitetura e Urbanismo, Universidade de São Paulo, São Paulo, 1994.

ZANTEN, David van.Architectural Composition at the École des Beaux-Arts from Charles Percier to Charles Garnier. In: DREXLER, Arthur (Ed.). The Architecture of the École des Beaux-Arts. London: Secker \& Warburg, 1984.

Artigo apresentado em 8/2007. Aprovado em 4/2008. 